\title{
Mental health nurses' attitudes, behaviour, experience and knowledge regarding adults with a diagnosis of borderline personality disorder: systematic, integrative literature review
}

Dickens, Geoffrey L.

Lamont, Emma

Gray, Sarah

This is the peer reviewed version of the following article:

Dickens, G. L., Lamont, E. and Gray, S. 2016. Mental health nurses' attitudes, behaviour, experience and knowledge regarding adults with a diagnosis of borderline personality disorder: systematic, integrative literature review. Journal of Clinical Nursing

which has been published in final form at doi: https://dx.doi.org/10.1111/ jocn.13202

This article may be used for non-commercial purposes in accordance with the Wiley Terms and Conditions for Self-Archiving 


\section{Mental health nurses' attitudes, behaviour, experience and} knowledge regarding adults with a diagnosis of borderline personality disorder: systematic, integrative literature review

Short title: Mental health nurses and borderline personality disorder

Geoffrey L. Dickens* RMN BSc(Hons) MA PGDip PhD, Professor of Mental Health Nursing, Abertay University, Dundee ${ }^{1}$ and NHS Fife ${ }^{2}$. Telephone: +44 7914157365 Email: g.dickens@abertay.ac.uk

Emma Lamont RMN MSc PG Cert HE, Nurse Lecturer, Abertay University, Dundee ${ }^{1}$ Telephone +44 1382348000

Email: e.lamont@abertay.ac.uk

Sarah Gray RMN MSc, Senior Research Nurse, NHS Fife ${ }^{2}$ Telephone +44 1383626623

Email: sarahgray1@nhs.net

* Corresponding author:

${ }^{1}$ Division of Mental Health Nursing and Counselling, Abertay University, Bell Street, Dundee. DD1 1HG. United Kingdom.

${ }^{2}$ NHS Fife Research and Development Department, Queen Margaret Hospital, Dunfermline KY12 0SU. United Kingdom.

N.B. this is a pre-print of a paper accepted for publication in Journal of Clinical Nursing. It is not the copy of record.

Word count excluding abstract, references, figures and tables: 6459 


\begin{abstract}
Aims and objectives

To establish whether mental health nurses responses to people with borderline personality disorder are problematic and, if so, to inform the content of interventions to support change.

\section{Background}

There is some evidence that people diagnosed with borderline personality disorder are unpopular amongst mental health nurses who respond to them in ways which could be counter-therapeutic. Interventions to improve nurses' attitudes have had limited success.
\end{abstract}

\title{
Design
}

Systematic, integrative literature review.

\section{Methods}

Computerised databases were searched from inception to April 2015 for papers describing primary research focused on mental health nurses' attitudes, behaviour, experience, and knowledge regarding adults diagnosed with borderline personality disorder. Analysis of qualitative studies employed metasynthesis; analysis of quantitative studies was informed by the theory of planned behaviour.

\section{Results}

$N=40$ studies were included. Only one used direct observation of clinical practice. Nurses' knowledge and experiences vary widely. They find the group very challenging to work with, report having many training needs, and, objectively, their attitudes are poorer than other professionals' and poorer than towards other diagnostic groups. Nurses say they need a coherent therapeutic framework to guide their practice, and their experience of caregiving seems improved where this exists.

\section{Conclusions}

Mental health nurses' responses to people with borderline personality disorder are sometimes countertherapeutic. Since interventions to change them have had limited success there is a need for fresh thinking. Observational research to better understand the link between attitudes and clinical practice is required. Evidence-based education about borderline personality disorder is necessary, but developing nurses to lead in the design, implementation, and teaching of coherent therapeutic frameworks may have greater benefits.

\section{Relevance to clinical practice}

There should be greater focus on development and implementation of a team-wide approach, with nurses as equal partners, when working with patients with borderline personality disorder.

\section{What does the paper contribute to the wider global clinical community}

- There is evidence that mental health nurses have relatively poor attitudes towards people diagnosed with borderline personality disorder.

- There is very little evidence that attitudes are linked to actual clinical behaviour

- Coherent and consistently applied therapeutic frameworks are viewed as important by nurses as well as education and practice development.

\section{Keywords:}

Mental health nurse, borderline personality disorder, emotionally unstable personality disorder, attitudes, experience, knowledge, education, systematic review. 


\section{Introduction}

People diagnosed with borderline personality disorder (BPD) experience pervasive and persistent instability of affective regulation, self-image, impulse control, behaviour, and interpersonal relationships (Lieb et al. 2004). Up to 6\% of adults meet diagnostic criteria during their lifetime, and the condition is associated with substantial psychiatric and physical morbidity (Grant et al. 2008). Management of people diagnosed with BPD is resource-intensive; there is a high rate of self-harm associated with disproportionate use of emergency (Elisei et al. 2012) and inpatient mental health services (Hayashi et al. 2010, Comtois \& Carmel 2014) while impulsive aggression is common (Látalová \& Praško 2010). It has been suggested that this group are unpopular amongst mental health practitioners (Cleary et al. 2002) who respond to them in ways which could be disconfirming (Fraser \& Gallop 1993), stigmatising (Aviram et al. 2006), or otherwise qualitatively different from how they respond to others, usually negatively so (Markham \& Trower 2003). Such practice potentially brings mental health nurses into conflict with professional requirements to act as a role model of integrity and leadership to others (e.g., Nursing and Midwifery Council 2015).

Despite this, previous reviews of the evidence about mental health nurses' attitudes towards people with BPD have lacked comprehensiveness, BPD-specific focus, or systematic rigour. Westwood and Baker (2010) reviewed the literature but restricted the scope of the review to nurses working in acute mental health settings; Saunders et al. (2012) have systematically reviewed studies of health professionals' attitudes about self-harming behaviour, but not specifically about people with BPD. Other reviews do not focus on the nursing profession, or are not systematic (Aviram et al. 2006, Ross \& Goldner 2009, Sansone \& Sansone 2013). It is important to systematically appraise and synthesise the available evidence since some studies (Bodner et al. 2011, Bodner et al. 2015b) have concluded that mental health nurses hold the poorest attitudes of all professional groups. We have recently conducted a systematic review of interventions that aimed to improve the attitudes and/or behaviour of groups of clinicians, including mental health nurses, towards people diagnosed with borderline personality disorder (Author 1 et al. In Press). The review revealed that only nine studies have been conducted. All studies were judged to be of moderate or poor methodological quality; common 
limitations included lack of a control group ( $n=7$ studies), blinding ( $n=9$ studies), randomisation ( $n=9$ studies), and robust outcome measures ( $n=7$ studies). There is some recent evidence that cognitive attitudes, notably knowledge, improve and are sustained following training interventions (Herschell et al. 2014, Stringer et al.2014, Clark et al. 2015), but little to suggest that affective attitudes or behaviour are improved. While there is therefore a case to conduct further intervention trials of greater rigour, there is also a need to systematically appraise and synthesise the wider body of empirical evidence about mental health nurses' attitudes, behaviour, experience, and knowledge regarding people with a diagnosis of borderline personality disorder. Such a synthesis could inform us about the extent to which mental health nurses responses to this group are problematic both in absolute terms and relative to their responses to other diagnostic groups, and those of other professional groups. Further, a greater understanding of the quality and nature of research into this important issue could inform the development of effective training interventions, should they be necessary, and aid the prioritisation of further research questions. We have therefore conducted a systematic review of the empirical literature on mental health nurses' nurses' attitudes, behaviour, experience, and knowledge regarding adults with a BPD diagnosis.

\section{Methods}

\section{Design}

We conducted a systematic literature review in accordance with the relevant sections of the Preferred Reporting Items for Systematic Reviews and Meta-Analyses (PRISMA) guidelines (Moher et al. 2009).

\section{Data collection}

The aim of the literature search was to identify empirical studies about mental health nurses' behavioural or attitudinal responses to, experience of, and knowledge about adults with a BPD diagnosis using a PICOT approach (see Table 1). Multiple computerised databases (CINAHL, PsycINFO, Medline, Biomedical Reference Collection: Comprehensive, Web of Science, ASSIA, Cochrane Library, EMBASE, ProQuest [including Dissertations/Theses], and Google Scholar) were 
searched. Comprehensive terms, utilising a wild card approach (ending with *) to ensure inclusion of all permutations, were employed (see Table 2 for example search). Hand searching of references lists from included studies was conducted to identify further records. Titles and abstracts were reviewed by [Author 1] and the full text version of any paper that described a potentially relevant empirical study was retrieved. Full text papers were reviewed independently by at least two of the authors.

>>Insert Table 1 here $<<$

> Insert Table 2 here $<<$

Inclusion/exclusion criteria. All primary research studies, including those in the grey literature (unpublished doctoral or Masters' theses, conference presentations, and government reports) that focused on mental health nurses' attitudes, behaviour, experience, or knowledge regarding BPD, or adults with a BPD diagnosis were eligible (see Table 1 for full criteria). We have previously reviewed studies of interventions aimed at improving nurses' attitudes, behaviour, and knowledge regarding BPD (Author 1 et al, In Press) and, while these papers were included because of their relevance to the specific study objectives, we did not include information about intervention effectiveness in the current study.

Study quality. Quantitative studies were assessed against criteria adapted from two sources (Greenhalgh 2006, University of York Centre for Reviews and Dissemination 2008). We further examined the data-collection instruments used to ascertain their psychometric properties including: i) internal consistency; ii) face, content, and construct validity; iii) test-retest and/or inter-rater reliability. Qualitative and mixed-methods studies were assessed against criteria, each adapted from two sources (Tong et al. 2007, Critical Appraisal Skills Programme 2013).

\section{Analysis}

Meta-analysis was not possible due to the range of methodologies and instruments used. Analysis of quantitative studies was informed conceptually by elements of the theory of planned behaviour (Ajzen, 1991) which provides a framework that has been widely used in healthcare to understand and 
predict health professionals' behaviour. The theory posits that an individuals' behaviour, and planned or intended behaviour, results from, inter alia, their emotional and cognitive attitudes about that behaviour; those attitudes may in turn be based on prior experience. Other elements in the theory highlight the role of subjective norms (what the actor believes that people will think about the way he acts), and perceived self-efficacy (their belief about their ability to act in a particular way). Thus, from this theoretical perspective, attempts to change behaviour will, at least partly, depend on attitudinal change. The theory was selected because the underlying assumption of a number of studies of interventions to improve mental health nurses attitudes towards people with BPD is, consistent with the theory, i.e., that this will result in improved behaviours (in the form of clinical practice), and ultimately in improved patient outcomes. Information about the aims, method, results, and implications of papers describing quantitative studies was extracted and tabulated in Microsoft Excel; results were then grouped in terms of their contribution to knowledge about i) nurses' attitudes, behaviours, experiences, and knowledge regarding people with BPD in absolute terms; and ii) the same variables but in relative terms; first relative to those of other healthcare professionals and second in relation to their own responses to people with other psychiatric diagnoses.

Analysis of qualitative studies employed a process of descriptive metasynthesis which is suitable for broad topics (Schreiber et al. 1997, Finfgeld 2003). It aims to use unaltered texts to provide data for analysis which involves identification of reciprocal and refutational relationships in study findings rather than an interpretative deconstruction of the underlying meaning of studies (Finfgeld 2003). Papers were read and analysed independently by [Authors 1 and 2]. Information about the findings of each study was extracted into a table in Microsoft Excel, read iteratively and sorted into groups with the aim of triangulating findings from studies that used heterogeneous methods and epistemological assumptions. Analyses were then discussed, summaries written and rewritten, and checked with the third author before final synthesis. Mixed-methods studies were included in both analyses. Studies were included in analyses irrespective of their quality; however, more robust studies were assigned greater weight in integration and discussion of their value. Further, the extent to which study findings were generalisable to mental health nursing was considered in our syntheses. 


\section{Results}

Study characteristics

The search strategy yielded 39 studies (see Figure 1) published between 1989 and 2015 conducted in 10 countries (UK, $n=11$; Australia $n=8$; US $n=7$; Canada $n=4$; New Zealand $n=4$; Ireland $n=3$; Israel $n=2$; Sweden, China, Greece all $n=1^{1}$ ). The largest group of studies were conducted in inpatient services $(n=15 ; 38 \%)$, including two in specialist BPD services; $n=14$ (36\%) across inpatient and community services; $n=7$ (18\%) only in community mental health services, one a specialist BPD service; $n=2$ with staff working in emergency services. The greatest number of studies $(n=15 ; 38 \%)$ included only registered nurse participants; eight samples (21\%) comprised $>50 \%$ registered nurse participants. Less than half of participants in $n=15$ studies (38\%) were nurses, including $n=3$ studies (8\%) with fewer than $10 \%$ nurse participants.

>>Insert Figure 1 here $<<$

Study methodology

Quantitative methods were used in $n=25$ (64\%) studies, qualitative research methods in $n=11$ studies (28, and $n=3$ (8\%) used mixed-methods. Quantitative studies employed cross-sectional, longitudinal, and observational designs. Interventions to improve the BPD-related knowledge and/or attitudes of participants were evaluated in $n=8(21 \%)$. Individual, semi-structured interviews were the most commonly used qualitative method; while focus groups, ethnography, and written accounts were used sparingly (see Table 6). Thematic analysis and interpretative phenomenology were the most common analytic strategies.

\section{Instruments}

Quantitative studies used a range of self-report instruments, and one used an observational tool. Qualitative studies employed purpose-designed semi-structured interview or focus group schedules while one used ethnographic observation, and another free-text written account.

\footnotetext{
${ }^{1}$ N.B. $N>39$ due to $n=3$ studies conducted in Australia and New Zealand.
} 


\section{Quality appraisal}

Quantitative studies met 2 to 11 of 12 quality standards (median=7). The most frequent limitations were: failure to justify sample size, use of unvalidated measurement tools, and lack of information about funding, conflicts of interest, or of the relationship between the authors' practice and the research. Twenty-four different data collection instruments were used in quantitative studies; for 11 there was no information available about external validity, internal consistency, or reliability, and, for a further nine, only one of these properties was established $\mathrm{m}$ (see Table 7). Qualitative studies met between 9 and 14 of 14 quality standards (median=12) while mixed-methods studies met between 5 and 8 of 16 standards $($ median $=8)($ see Tables $3-5)$.

>>Insert Tables 3,4, and 5 here $<<$

\section{Analysis of quantitative studies}

Mental health nurses' attitudes, behaviours, experience and knowledge: non-comparative studies. Cleary et al's (2002) survey questionnaire has been used in five investigations in total (Cleary et al. 2002, Hazelton et al. 2006, James \& Cowman 2007, Giannouli et al. 2009, Strong 2010). Prior attendance at BPD-specific training has been reported by 3\%-32\% of respondents; $20 \%-70 \%$ reported daily to weekly contact with individuals diagnosed with BPD; few (0\%-9\%) reported no contact. Current services were rated inadequate (66\%-90\%); cited reasons were shortage of services (45\%$98 \%)$, difficult to treat patients (26\%-88\%), lack of staff training (29\%-62\%), and disagreement among the therapeutic team (16\%-83\%). With regard to BPD-related knowledge, most participants correctly identified that BPD involves unstable, rapidly shifting mood (75\%-85\%), and impulsive and self-destructive behaviour (72\%-92\%); fewer (25\%-50\%) correctly disagreed that it is characterised by grandiose self-importance. Most (70\%-78\%) correctly identified that short-term psychotherapy can be a useful treatment, but fewer (37\%-62\%) correctly disagreed that hospitalisation should not be considered. Most (58\%-68\%) correctly disagreed that antidepressant treatment is of no benefit for treatment of depression in those with BPD, and that BPD is a precursor to schizophrenia (50\%-70\%). Respondents were moderately to very confident in the identification (62\%-80\%), assessment (41\%- 
$75 \%)$ and management (48\%-86\%) of clients with BPD. Few (25\%-33\%) respondents had knowledge of specialist services or how to refer patients (32\%-33\%). Most (74\%-86\%) believed that BPD patients are difficult to treat, $65 \%-84 \%$ stated that they are more difficult to treat than other patients; however, the vast majority agreed that they have a role in assessment (86\%), management (91\%), referral (83\%), and education (86\%) (Cleary et al. 2002). Finally, almost all (90\%-100\%) respondents agreed they want more education and training, and would be willing to devote at least 1hour per month to it. Respondents endorsed that they wanted more information about where to refer BPD clients (38\%-80\%), skills training workshops (51\%-76\%), regular in-service training and education (48\%-74\%), clear nursing protocols (55\%-59\%), and specialist BPD services (49\%-70\%).

Other surveys have revealed a high level of endorsement $(80 \%+)$ of the statements: 'BPD patients' prognosis is hopeless'; 'I would like to avoid caring for this group' (Black et al. 2011); and 'patients with BPD are manipulative' (Deans \& Meocevic 2006); and moderate endorsement (51\%) that 'these patients emotionally blackmail people they work with' (Deans \& Meocevic 2006). Most (71\%) nurses in McGrath and Dowling's (2012) study responded to a vignette about a BPD-diagnosed patient with multiple hospital admissions in ways that were classified as uncaring, for example, 'providing information about the rules'. More (59\%) participants gave responses that were categorized as 'offering solutions' to a similar vignette in which the protagonist had a single inpatient admission. Elsewhere (Krawitz \& Batcheler 2006), 85\% of respondents agreed that they had employed defensive practices (prolonged acute hospitalization, lengthy one-to-one observation of the patient, or frequent or lengthy use of mental health legislation) in order to protect themselves from perceived medicolegal repercussions. Finally, in relation to knowledge, participants in Clark et al. (2015) study lacked knowledge at baseline related to genetics, neuroanatomy and cognitive dysfunction in BPD.

Mental health nurses' attitudes, behaviours, experience and knowledge: comparative. Nurses in Bodner et al's (2015) large survey self-reported more negative cognitive attitudes about BPD patients than psychiatrists, psychologists, and social workers in terms of evaluation of suicidal tendencies; and more negative attitudes than social workers and psychologists, but not psychiatrists, on the necessity for hospitalisation. Results remained significant after controlling for potential covariates (gender, 
seniority, ward type, level of BPD-specific education, number of BPD patients treated, reported knowledge about DBT, and reported level of practice with BPD patients). Further, nurses reported significantly less empathy compared with social workers and psychologists, but not psychiatrists; again, this remained significant after controlling for covariates. These results largely replicated and extended the researchers' previous study (Bodner et al. 2011). Additionally, nurses' negative attitudes were correlated with the number of BPD patients treated in the past month and past 12-months; whereas, for the other professions, exposure to more BPD patients was actually associated with a reduction in negative attitudes. In a similar study, Black et al. (2011) sought responses to 15 statements about patients diagnosed with BPD. Nurses performed relatively poorly on all three summary scores: significantly lower than social workers on empathy; for treatment optimism and caring attitudes nurses scored more poorly than all other professional subgroups. Items on which nurses rated significantly more negative attitudes were: use of intentional manipulation, viewing BPD as a distressing illness, the usefulness of medication or psychotherapy interventions, ability to make a positive difference, and viewing BPD as a hopeless prognosis. In contrast to Bodner et al. (2015), clinicians who cared for more BPD patients over the past year had the more positive attitudes.

However, Bodner's (2015) use of better survey tools and occupation-level analysis of nurses' attitudes makes his account the more compelling.

Markham and Trower (2003) analysed their data for attitudinal differences between registered nurses and healthcare assistants. While both groups rated their desire for social distance from BPD patients higher than for patients with depression, nurses also rated their desire for social distance from BPD patients higher than from those with schizophrenia. A similar pattern was discernible on ratings of dangerousness. Both groups rated their experience of working with people with BPD and their treatment optimism as more negative than working with other groups of patients. For nurses, there was a significant correlation between dangerousness ratings and desire for social distance from BPD and schizophrenia patients. Finally, Commons Treloar and Lewis (2008a) investigated attitudes to deliberate self-harm among health practitioners working in emergency medicine departments or 
mental health settings. Mental health practitioners had significantly better attitudes than emergency medicine practitioners; the difference yielded a large effect size.

>>Insert Table 6 here $<<$

A number of studies have compared mental health nurses' responses to people with BPD relative to those with other psychiatric diagnoses. In the sole study using direct-observation of behaviour (Gallop et al. 1989), nurses verbal interactions in therapy groups with patients diagnosed with either BPD, schizophrenia, or affective disorder were rated as confirming or disconfirming. Diagnostically blind observers noted no differences in patients' behaviour, or the nature of their interactions with nurses by diagnosis. Nurses' verbal responses to BPD patients were more likely to be categorized as 'impervious' and 'indifferent' than to patients with affective disorder, but not to those with schizophrenia.

Knaak et al. (2015) randomised community and outreach workers to answer stigma-related questions either about mental illness or specifically about BPD before and after delivery of a BPD-specific educational and skills program. Analysis revealed significantly higher stigma in domains about negative attitudes, willingness to disclose/seek help, and preference for social distance for thosecompleting the amended BPD version than those completing the original questionnaire.

Bodner et al. (2015) presented respondents with a vignette describing a 25-year old woman with a recent three-month hospitalization, post-discharge relapse of suicidal ideation, and recurrent emergency department presentations. Vignettes were randomised such that one third of the sample were told the woman was diagnosed with BPD, one third with Major Depressive Disorder (MDD), and one third with Generalised Anxiety Disorder (GAD). Since participants received only one version of the vignette the authors regarded the associated scale as an implicit measure of attitudes towards the decision to hospitalize, length of stay, and quality of treatment received; and as of further implicit measures of attitudes towards 13 items representing patient traits (e.g., co-operative-uncooperative). The decision to hospitalize the patient was viewed as less justified for the BPD than the MDD, but not the GAD, vignette; length of treatment was, contrary to hypothesis, viewed as less justified for the GAD but not the BPD or MDD patients. There was no difference in terms of estimation of quality of 
treatment between the groups. The decision to hospitalize a patient with BPD was perceived more negatively than that of the MDD patient, and attribution of negative traits in the BPD vignette was stronger than in the MDD condition. Further, those with BPD were viewed significantly more negatively than MDD, but not GAD, on selfish, manipulative, dramatic, and passive traits. An earlier study (Bodner et al. 2011) suggested that much of the antipathy towards BPD patients could be explained by respondents' attitudes towards the suicidal and self-harming behaviour of these patients.

Forsyth (2007) surveyed nurses and support workers using a questionnaire about anger, empathy and helping behaviour after reading vignettes about patients failing to perform allotted therapeutic tasks. Participants were presented with scenarios describing those with BPD and MDD diagnoses for all possible combinations of dichotomized attributed controllability (is the patient in control of their behaviour?) and stability (would the patients behaviour usually be the same in this situation?). Respondents reported significantly greater willingness to help those with depression than BPD. Irrespective of diagnosis, respondents reported greater anger when they perceived non-compliance as both controllable and stable.

Markham and Trower (2003) investigated whether BPD, schizophrenia, and depression diagnostic labels were associated with mental health nurses' causal attributions about patients' behaviour and their perceptions of event controllability. Respondents imagined a patient with a particular diagnosis and were presented with six examples of challenging behaviour that she might display (e.g., refusing a staff request). Nurses rated the cause of this behaviour with regard to their attributions about its' internality (person or environmental cause), stability (extent to which it was likely to be the same each time it occurred), and globality (extent to which it will influence other events). Further self-ratings were made of the patients' ability to control the cause of behaviour and the event itself, sympathy and treatment optimism for the patient, and prior experience of working with each patient group. When considering people with $\mathrm{BPD}$, nurses provided significantly higher ratings than in comparison conditions on stability, and on attributed controllability of behaviour and the event itself. Further, nurses made less positive ratings of sympathy, optimism, and prior positive experience when considering those with BPD. In a related study (Markham 2003), participants rated their desire for 
social distance from BPD patients significantly greater than for depression or schizophrenia; for example, they were less positive about BPD patients than others on items about their willingness to live in the same area as them, or willingness to employ them. Respondents rated BPD patients as more dangerous than other groups, had less optimism for them, and reported significantly poorer experience of working with them. Finally, there was a significant relationship between nurses' ratings of desire for social distance and their beliefs about the dangerousness of people with BPD. Strong (2010) presented alternate participants with one of two vignette case studies, which differed only on the diagnostic label used (BPD or depression), about a female service user who had self-harmed before presenting to her GP. Both were rated equally on dangerousness and controllability; willingness to use coercive measures and desire for social distance were significantly more likely in the BPD vignette condition, and intended helping behaviour significantly less. For the BPD scenario, a fearful emotional reaction was positively associated with intended coercion and negatively with intended helping behaviour; anger was also negatively associated with intended helping behaviour.

Respondents in the BPD scenario reported anger, but not pity or fear, more than control participants. Finally, greater BPD-related knowledge correlated negatively with attribution of controllability in the BPD condition; and knowledge of BPD-treatment correlated negatively with intended coercion and positively with intended helping behaviour indicating that training that improves knowledge may have positive effects on attitudes.

Nurses participating in Fraser and Gallop's (1993) observational study rated their emotional response to vignettes of patients diagnosed with schizophrenia, affective disorder or BPD. Schizophrenia and affective disorder vignettes received higher positive emotion and lower negative emotion ratings than BPD vignettes. In an earlier study, Gallop et al. (1989) nurses' written free narrative responses to vignettes where diagnosis was manipulated such that patients with similar clinical presentations were designated with a BPD or schizophrenia label. Participants expressed more empathy towards schizophrenia than BPD vignettes; conversely, there were more belittling and contradictory responses to BPD vignettes. In order to determine whether nurses stereotyped individual BPD patients in terms of their diagnostic category, Amey (1992) examined their responses to real individual patients with 
diagnoses of either BPD, schizophrenia or affective disorder compared with their previously elicited response on the same scale about each patient diagnostic group. As such, the term stereotype was used to connote congruence between pre-existing beliefs about the characteristics about a group and subsequent assumptions about those of an individual group member rather than to connote prejudice or discrimination on the part of respondents. Stronger stereotyping, it was argued, would result in little difference between ratings for individuals and corresponding diagnostic groups. Analysis revealed that, since there was least difference between the two ratings in the BPD condition, that BPD vignettes were not stereotyped compared with schizophrenia and affective disorder vignettes. In fact, the two comparison groups were stereotyped in terms of participants' emotional responses but not their perception of the patients' problems. The author concluded that the wide repertoire of behaviours displayed by BPD diagnosed individuals may lead to nurses' formulating a more individually-oriented impression deviating more from expectation than for people with other diagnoses.

\section{Qualitative metasynthesis}

The metasynthesis yielded three themes; all studies featured included these to some extent.

Human response. Each study acknowledged the human responses which practitioners experienced when working with BPD-diagnosed individuals. Responses ranged from empathy, warmth, and interest in treatment (Bergman \& Eckerdal 2000, Bowen 2013) to frustration, inadequacy, powerlessness, anger, and therapeutic nihilism (Bergman \& Eckerdal 2000, Woollaston \& Hixenbaugh 2008, Commons Treloar 2009, Kale \& Dantu 2015). These responses had reported personal, psychological, and somatic impacts including fatigue, distress, and desensitisation; but in some cases realistic optimism and admiration (Cotes 2004, Woollaston \& Hixenbaugh 2008, Ma et al. 2009, Bowen 2013, Warrender 2015). Studies commonly noted the emotional impact that working with these individuals can have, and practitioners identified intrusive thoughts, feelings of responsibility, and coping with suicide threats as the most distressing aspects of care (Cotes 2004, McGrath \& Dowling 2012, Kale and Dantu 2015). This may partly explain why (Woollaston \& Hixenbaugh 2008) (p.705) identified that nurses viewed this patient group as 'a powerful, dangerous, 
unrelenting, and unstoppable force'. Others (Hazelton et al. 2006) (p.126) described the group as 'troubling', and 'difficult to warm to', or more complex, chaotic and time consuming than other people (Cotes 2004). These mixed responses also reportedly impacted upon care; both negatively (e.g., avoidance, refusal to treat) (Nehls 2000, McGrath \& Dowling 2012), and positively, for example by harnessing empathy as an ingredient for positive change (Bowen 2013). This polarisation was evident in studies where participants reported dread at going to work versus a desire to help, and understanding distress alongside setting boundaries (Nehls 2000, Ma et al. 2009, Stroud \& Parsons 2013). 'Being manipulative' and 'attention seeking' were common terms used about the diagnostic group (Hazelton et al. 2006, Commons Treloar 2009, McGrath \& Dowling 2012). Despite some prominent negative attitudes it was evident across studies that practitioners who reported more positive human responses had attitudes and an approach to care that was hopeful; where this was nurtured, a more optimistic outlook emerged (Bergman \& Eckerdal 2000, Ma et al. 2009, O'Connell \& Dowling 2013, Stroud \& Parsons 2013, Bowen 2013). This was reinforced by Bowen's study (2013) within a specialist BPD service which supported the benefits of a culture whereby patients were involved in decisions through a process of shared and open communication and encouraged to develop relationships thereby working out interpersonal difficulties in a safe and supportive community. Vital to successful change in two studies was access to peer support, and practitioners who had a positive attitude about health outcomes (Ma et al. 2009, Bowen 2013).

Therapeutic frameworks. The perceived essential elements of successful therapeutic frameworks were discussed including how they shape and guide care, and how their absence can impact negatively on nursing care. Stroud and Parson's (2013) study of community mental health nurses found that a shared vision of treatment, and the existence of a framework to understand behaviour, was common among those with consistently positive attitudes. Bowen's (2013) exemplar study advocated for a therapeutic community approach entailing open communication, shared decision making, a culture of enquiry, and engagement in dialogue to resolve problems. Key aspects of care involved acknowledging difficult past experiences including abuse, unconditional acceptance despite selfdestructive behaviour, and recognition of individual strengths and personality. Alongside this, Bowen 
(2013) describes how group-based therapy, peer support, and involvement of patients in risk assessment are embedded within their therapeutic framework. Similarly, Warrander (2015) found that mentalisation based treatment skills training (MBT-S) combined a flexible, common-sense approach with an element of structure. Staff trained in MBT-S felt they had increased empathy, a new confidence to talk with individuals about self-harm, and understand emotional states; they identified MBT-S as a useful tool which has a positive impact and allows the team to tolerate risk more readily. Elsewhere, studies highlighted that care should focus on normalisation, and non-stigmatising, recovery-focused interventions (Nehls 2000, Forsyth 2010). Ma et al. (2009) discussed individualised, needs-based care, and found this to be more evident where practitioners expected positive outcomes, viewing behaviours as modifiable. Such nurses were likely to provide personalised interventions based on individual needs and preferences. A number of studies identified unsatisfactory care experiences along with participants recognising the need for a therapeutic framework particularly given the difficulty of engaging individuals in treatment (Bergman \& Eckerdal 2000, Nehls 2000, Ma et al. 2009, Forsyth 2010, O'Connell \& Dowling 2013, Kale and Dantu, 2015). Furthermore, O'Connell \& Dowling (2013) discussed how the absence of a therapeutic framework to guide practice could lead to care focused upon setting boundaries, and self-monitoring. This was highlighted in Nehls (2000) study of case managers where participants felt they were viewed as uncaring, were keen to dispel any illusions of friendship, and actively limited activities and interventions with patients. Ma et al. (2009) identified that, without a formal therapeutic framework, highlighted as key to nurses' sense of therapeutic optimism and empowerment in Bowen (2013) and Warrender's (2015) studies, a team approach to care was perceived as more difficult to establish. Their analysis suggested that, in these circumstances, nurses feel unsupported, isolated, and unwilling to seek support. Nurses expressed that they would have welcomed a forum to seek support, most notably clinical supervision such as that offered in study settings where a therapeutic framework was in place (e.g., Stroud \& Parsons 2013, Bowen 2013, Warrender 2015).

Practice development. This theme comprised elements about culture, education, and clinical supervision. Practitioners expressed concerns that the current health system is inadequate (Commons 
Treloar 2009) and suggested that more education and clinical supervision is needed (McGrath \& Dowling 2012, O'Connell \& Dowling 2013, Warrender 2015, Kale \& Dantu 2015). Some studies report that specialist services are required and access to education, training and resources are hampered by service constraints including time, teamwork, workload, and financial restrictions (Commons Treloar 2009, Forsyth 2010, Stroud \& Parsons 2013, Bowen 2013, Warrender 2015). The prevailing culture is viewed as impacting on staff attitudes and, where there is little education, training, and supervision, negative attitudes are likely to be fostered (Bergman \& Eckerdal 2000); additionally, practice can be influenced by teams' discourse which can maintain stereotyped views (Forsyth 2010). Practitioners' identified the need for education and training through workshops, conference attendance, and access to research results (Bergman \& Eckerdal 2000, Hazelton et al. 2006, Woollaston \& Hixenbaugh 2008b, Commons Treloar 2009, McGrath \& Dowling 2012, Bowen 2013, Kale \& Dantu, 2015). Desired educational topics include advice on utilisation of conceptual or therapeutic frameworks (Commons Treloar 2009, O'Connell \& Dowling 2013, Stroud \& Parsons 2013); skills training in treatments including cognitive behavioural therapy (CBT) (Bergman \& Eckerdal 2000, Woollaston \& Hixenbaugh 2008b, McGrath \& Dowling 2012); dialectical behavioural therapy (DBT) (Cotes 2004, Hazelton et al. 2006); and mentalisation based treatment skills training (MBT-S) (Warrender 2015); understanding of clinical presentation, predisposing factors and childhood trauma (McGrath \& Dowling 2012, O'Connell \& Dowling 2013, Stroud \& Parsons 2013); self-management (O'Connell \& Dowling 2013); clinical and risk assessment (Commons Treloar 2009, O'Connell \& Dowling 2013); development and maintenance of therapeutic relationships (Nehls 2000, McGrath \& Dowling 2012); understanding diagnosis and treatment planning, crisis planning, collaborative and team approaches (Bergman \& Eckerdal 2000, Nehls 2000); recovery, peer support, strengths approach, and therapeutic communities (Nehls 2000, Bowen 2013).

Stroud and Parsons (2013) discussed education as having a greater impact than experience in the attitudes of practitioners, and Warrender (2015) found attitudes improved following a two day workshop in MBT-S such that participants described patients as being less difficult and expressed a 
more profound understanding of the intent of patients' behaviour. Similarly a DBT training programme (Hazelton et al. 2006) involving a two day beginner and a two day advanced workshop was popular and, in focus groups, practitioners described a better understanding of BPD.

Clinical supervision is frequently advocated (Bergman \& Eckerdal 2000, Woollaston \& Hixenbaugh 2008b, Commons Treloar 2009, McGrath \& Dowling 2012, Stroud \& Parsons 2013, Warrender 2015) and viewed as good practice within therapeutic approaches including DBT, MBT-S and CBT (Stroud \& Parsons 2013, Bowen 2013, Warrender 2015). In order to make effective use of training, maintain knowledge, and ensure fidelity to the therapeutic model of choice, practitioners need to receive regular clinical supervision which addresses their own internal processes (Woollaston \& Hixenbaugh 2008b, Stroud \& Parsons 2013, Warrender 2015). Yet despite this, there was a reported lack of opportunity; many practitioners had not received any formal clinical supervision and informal arrangements left them feeling frustrated and helpless (Commons Treloar 2009, McGrath \& Dowling 2012, Stroud \& Parsons 2013, Warrender 2015).

\section{Discussion}

This systematic review of the empirical literature about mental health nurses' attitudes, behaviour, experiences, and knowledge regarding people with a psychiatric diagnosis of BPD identifies and provides a critical overview of the current evidence, an important consideration since one third of included studies were published in the past 5-years. Our aims were threefold. First, in the context of recent findings that interventions to improve mental health nurses' responses and attitudes to, and knowledge about, people with BPD, (Author 1 et al. In Press) have had limited success, we aimed to identify whether such interventions are needed. Second, in the event that they are necessary, we aimed to determine what we can learn from the current empirical literature about what successful interventions might look like. Finally, we aimed to identify future research priorities emerging from our review.

The need for interventions 
Qualitative studies have largely explored mental health nurses experiences' of BPD-related care provision. Nurses perceive people diagnosed with BPD as a highly challenging group to work with; they described responding in diverse ways, including some which may be unhelpful both for their patients and themselves, and which run contrary to the values of mental health nursing (NewtonHowes et al. 2008) and relevant professional standards (e.g., Nursing and Midwifery Council, 2015). However, attitudes were not universally poor and the human response theme revealed by our analysis incorporated numerous descriptions of compassionate and empathetic concern. Similarly, quantitative cross-sectional survey studies revealed a mixed picture regarding attitudes, experience and knowledge; while these studies have no doubt been useful in identifying local training and development needs, the wide variation in results suggests they might have little generalisability outside of their immediate setting.

Next, we turn our attention to the issue of whether mental health nurses have specific BPD-related development needs by looking at what we can learn from studies that investigate their attitudes, behaviours, and knowledge relative to those of other professional groups or relative to their responses to other diagnostic groups. There has been a single observational study involving the behaviour of nurses regarding people diagnosed with BPD. Mental health nurses were objectively rated as providing qualitatively poorer care, in the form of verbal responses, to people with BPD than other patients (Fraser \& Gallop 1993). Given the scale of interest in the subject this dearth of direct observational evidence is surprising. All other evidence about the relatively poor responses of mental health nurses has been derived from self-report measures of reactions to written clinical scenarios. While the theoretical links (Ajzen 1991) between attitudes and practice have been demonstrated in a number of studies of healthcare practitioners these have largely been demonstrated in relation to easily observable and quantifiable behaviours such as prescribing compliance and glove-wearing (Godin et al 2008). The almost exclusive use of written vignettes in BPD-related attitudinal research speaks to the difficulty of investigating such a complex area of practice directly; instead we are left only with studies using hypothetical clinical vignettes. While study designers have asserted that results from vignette studies have some generalisability to actual practice they may lack ecological 
validity (Hughes \& Huby 2002). Nevertheless, they have long been used to identify underlying, nonobservable causal phenomena (Evans et al. 2015) and there was a consistent pattern in included studies of practitioners responding differently to scenarios that varied only on patient diagnosis: clinicians had more negative responses to BPD-related scenarios than others with regard to reduced empathy (Gallop et al. 1989, Forsyth 2007), sympathy (Markham 2003), optimism (Markham 2003, Markham \& Trower 2003), intention to help (Strong 2010), positive feelings (Fraser \& Gallop 1993), and positive experience of working with the group (Markham 2003, Markham \& Trower 2003); and less positive responses with regard to desire for social distance (Markham 2003, Strong 2010), perceived dangerousness (Markham 2003, Strong 2010), negative feelings (Fraser \& Gallop 1993), stigma (Knaak et al. 2015), and belittling or contradictory remarks (Gallop et al. 1989). Research evidence has not supported claims of differences in intended coercion (Strong 2010), stereotyping (Amey 1993), or anger and fear (Forsyth 2007). In addition, mental health nurses have consistently performed more negatively than other professional disciplines in terms of response to vignettes on BPD-related cognitive and emotional attitudinal measures, beliefs about dangerousness, and desire for social distance (Markham 2003, Black et al. 2011, Bodner et al. 2011, Bodner et al. 2015). Despite the limitations of vignette studies, we think that such consistent findings indicate that there are particular BPD-related developmental needs in the mental health nursing workforce.

\section{The content of interventions}

To date, interventions to improve mental health nurses attitudes towards people with BPD have had limited success (Author 1 et al. In Press). Thus, while nurses probably have developmental needs, and those needs are more acute than other mental health professionals, it has not yet been established what the content of interventions to address those needs should be. Currently, the best evidence is that knowledge-deficits are the most amenable to change through traditional teaching methods (e.g., Clark et al. 2015). Given that nurses attribute greatest self-controllability to BPD-diagnosed patients relative to other groups (Markham \& Trower 2003, Forsyth 2010), a finding that could be problematic since such an attribution was related to negative emotions, there is a plausible potential mechanism to link knowledge with affect in the case of BPD. In surveys and qualitative studies nurses have consistently 
stated that they want more information, training and development opportunities about BPD and we conclude that evidence-based information about epidemiological, aetiological, care and treatment aspects of BPD should form the cornerstone of routine training. There is no good evidence to indicate that these might be best delivered in face-to-face sessions rather than through other media such as workbooks or e-based learning.

Surveys and qualitative studies have, more importantly, revealed a desire among nurses for comprehensive therapeutic frameworks and formalised support for those working with people diagnosed with BPD. The most intensive intervention to be investigated thus far in terms of its ability to improve attitudes examined the effect of a 22-month programme of DBT training (Herschell et al. 2014) and, while cognitive attitudes, most notably knowledge, measurably improved there was no detectable difference in affective attitudes. Similar findings in studies by Stringer et al. (2014) and Shanks et al. (2011), which evaluated the effect of a 3-day collaborative care programme training and a Systems Training Emotional Predictability \& Problem Solving (STEPPS) programme respectively, suggest little measurable gain in affective attitudes as a result of training. However, the primary purpose is improving patient outcomes, and some have had a measure of success in that regard despite the apparent failure to improve staff attitudes (Herschell et al. 2014, Stringer et al. 2014). From this perspective, while education and training is important, we should be more concerned about whether interventions improve patient outcomes than whether they affect nurses' attitudes. Interestingly, there is some recent evidence that it is the very protocol-driven nature of these structured approaches to working with patients that some nurses find difficult (Stringer et al 2014b); therefore, it may be of greater value to support nurses to take a full part in the development, implementation, delivery, and evaluation of structured approaches rather than focus on relatively simple educational interventions. Some of the best evidence (Bodner et al. 2015) suggests that it is nurses' attitudes, uniquely, which become more negative as they spend more time with the patient group; and that those attitudes are not the result of a range of other covariates. Bodner et al.'s (2015) speculation that discipline-based differences may therefore be attributable to nurses' relative lack of control over their caseload is an important insight. That practitioners - the majority nurses - working in emergency medicine 
departments had even poorer attitudes than mental health nurses (Commons Treloar \& Lewis 2008) might support the case for nurse-specific reasons for attitudinal differences. It is interesting that, to date, there has been no research into the effect of structural interventions, such as providing regular, high quality clinical supervision or allowing nurses' to regulate their face-to-face contact time with patients.

\section{Future research considerations}

The evidence base in respect of differential attitudes has been strengthened substantially by recent large scale studies (Black et al. 2011, Bodner et al. 2015). However, neither study used tools in which external validity had been ascertained and future research should remedy this shortfall. Future research using vignette methodology should strive to ensure that scenarios are properly validated and that tools with established psychometric properties are used. However, attitudinal change, particularly in relation to affective change, has proved difficult to measure and it is now time to focus on more potentially fruitful designs. We suggest that observational research should be prioritised. With suitable precautions it is possible to undertake such studies in mental health care facilities (e.g., Ryan $\&$ Bowers 2005). There is considerable scope to enrich the field using ethnographic or other observational approaches. Observation should also form part of any further studies that aim to link behaviour with attitudes since this has proved useful in other studies of healthcare behaviour change (Godin et al. 2008).

There is considerable scope to determine what type of training might have the best effects, for example in head-to-head comparisons of factually-based educational interventions and others aimed at improving knowledge. However, while nurses tell us that they need this sort of development they also want more coherent therapeutic frameworks in practice which may require something more than targeted educational interventions. Mental health nurses should be supported to be leaders and implementers of such therapeutic frameworks on an equal footing to their colleagues in psyuchiatry and psychology. Finally, if control over caseload is a uniquely important issue for mental health nurses (Bodner et al. 2015) then we suggest that organisational level interventions might be useful: 
for example, organising services so that nurses can rotate periodically into and out of contact with BPD patients. Other complex interventions, for example provision of clinical supervision, might be also trialled in relation to BPD-related attitudes.

\section{Limitations}

Our review is limited by the absence of high quality evidence, and the lack of a demonstrable link between attitudinal change, practice and patient outcomes. We lacked the resources to include nonEnglish language studies, and chose not to include studies about attitudes to the broader category of personality disorder, of which there have been a number of empirical investigations. A surfeit of studies also used tools with limited psychometric properties. A number of studies included participants who were not mental health nurses and did not present separate data; therefore, especially given those studies which found differences between nurses and other professional groups, it is possible that studies with mixed participant groups are not entirely representative.

\section{Relevance to clinical practice}

Our review provides a timely reminder that the longstanding issue of nurses' responses to people with borderline personality disorder remains a live issue, and one that generates considerable frequency and intensity of debate in professional circles. By synthesising and summarising the existing empirical literature base in the context of its' quality the current paper is relevant in a number of ways. Given the apparently poor attitudes held (Bodner et al. 2015), mental health nurses should continue to request and take advantage of opportunities for theoretical and skills-related development opportunities related to borderline personality disorder. Given evidence that nurses valued supervision and a structured approach to care of this group (Bowen 2013) then, where these are not occurring, nurses should take the initiative to develop more supportive ways of working; incorporating more informal peer support, formal clinical supervision, and the support of other professions in developing appropriate coping strategies. Other unique aspects including, in inpatient settings, 24-hour responsibility 
for care, might negatively impact on attitudes. If these suggestions are correct then it appears that educational interventions will not be adequate to address the structural nature of this profession-wide concern.

\section{Conclusion}

Mental health nurses aim to provide respectful and equal care. This review suggests that, at least relative to other professions and other diagnostic groups, they are failing to do this in the case of people diagnosed with BPD. Educational interventions to improve knowledge and skills are desired, demanded, and valued but may be insufficient. Further theoretical development about links between attitudes and behaviour is required. 


\section{References}

*References included in the systematic review

Ajzen I (1991). The theory of planned behavior. Organizational Behavior and Human Decision Processes 50, 179-211.

Allen A \& Links PS (2012) Aggression in borderline personality disorder: evidence for increased risk and clinical predictors. Current Psychiatry Reports 14, 62-69. DOI: 10.1007/s11920-011-0244-9

*Amey SE (1992) Nurses' stereotypically-oriented versus individually-oriented perceptions of and responses to psychiatric patients: Are individual borderline patients stereotyped? Ottawa: National Library of Canada = Bibliotháeque nationale du Canada. ISBN: 9780315784260

Author 1, A.N.Other, Author 2(In Press) Interventions to Improve mental health nurses' skills, attitudes, and knowledge related to people with a diagnosis of borderline personality disorder: systematic review. International Journal of Nursing Studies. DOI:

10.1016/j.ijnurstu.2015.10.019

Aviram RB, Brodsky BS \& Stanley B (2006) Borderline personality disorder, stigma, and treatment implications. Harvard Review of Psychiatry 14, 249-256.

Bailey BA, Hare DJ, Hatton C \& Limb K (2006) The response to challenging behaviour by care staff: emotional responses, attributions of cause and observations of practice. Journal of Intellectual Disability Research 50, 199-211. DOI: 10.1111/j.1365-2788.2005.00769

*Bergman B \& Eckerdal A (2000) Professional skills and frame of work organization in managing borderline personality disorder: shared philosophy or ambivalence. A qualitative study from the view of caregivers. Scandinavian Journal of Caring Sciences 14, 245-252. DOI: 10.1111/j.1471-6712.2000.tb00592.x

*Black DW, Pfohl B, Blum N, McCormick B, Allen J, North CS, Phillips KA, Robins C, Siever L, Silk KR, Williams JBW \& Zimmerman M (2011) Attitudes toward borderline personality disorder: A survey of 706 mental health clinicians. CNS Spectrums 16, 67-74. DOI: $10.1017 / \mathrm{S} 109285291200020 \mathrm{X}$

*Bodner E, Cohen-Fridel S \& IancuI (2011) Staff attitudes toward patients with borderline personality disorder. Comprehensive Psychiatry 52, 548-555.

DOI: 10.1016/j.comppsych.2010.10.004

*Bodner E, Cohen-Fridel S, Mashiah M, Segal M, Grinshpoon A, Fischel T \& IancuI (2015) The attitudes of psychiatric hospital staff toward hospitalization and treatment of patients with borderline personality disorder. BMC Psychiatry 15:2. DOI: 10.1186/s12888-014-0380$\mathrm{y}$

*Bowen M (2013) Borderline personality disorder: clinicians' accounts of good practice. Journal of Psychiatric and Mental Health Nursing 20, 491-498. DOI: 10.1111/j.13652850.2012.01943.x 
*Clark CJ, Fox E \& Long CG (2015) Can teaching staff about the neurobiological underpinnings of borderline personality disorder instigate attitudinal change? Journal of Psychiatric Intensive Care 11, 43-51. DOI: 10.1017/S1742646414000132

*Cleary, M., Siegfried N \& Walter G (2002) Experience, knowledge and attitudes of mental health staff regarding clients with a borderline personality disorder. International Journal of Mental Health Nursing 11, 186-191. DOI: 10.1046/j.1440-0979.2002.00246.x

*Commons Treloar AJ (2009) A qualitative investigation of the clinician experience of working with borderline personality disorder. New Zealand Journal of Psychology 38, 30-34.

*Commons Treloar AJ \& Lewis AJ (2008) Targeted clinical education for staff attitudes towards deliberate self-harm in borderline personality disorder: randomized controlled trial. Australian and New Zealand Journal of Psychiatry 42, 981-988. DOI: 10.1080/00048670802415392

Comtois KA \& Carmel A (2014) Borderline personality disorder and high utilization of inpatient psychiatric hospitalization: Concordance between research and clinical diagnosis. Journal of Behavioral Health Services and Research, 1-9. DOI 10.1007/s11414-014-9416-9

*Cotes EJ (2004) Stress, burnout and the attitudes and experiences of mental health professionals working with clients who meet the criteria for a diagnosis of personality disorder. DClinPsych thesis, University of Warwick. Available: http://wrap.warwick.ac.uk/1208/ (Accessed: 25 September 2015)

Critical Appraisal Skills Programme (2013) 10 questions to help you make sense of qualitative research. Available: http://www.casp-uk.net/wp-content/uploads/2011/11/CASPQualitative-Research-Checklist-31.05.13.pdf (Accessed: 25 September 2015)

*Deans C \& Meocevic E (2006) Attitudes of registered psychiatric nurses towards patients diagnosed with borderline personality disorder. Contemporary Nurse 21, 43-49

Dziopa F \& Ahern KJ (2009) What makes a quality therapeutic relationship in psychiatric/mental health nursing?: A review of the research literature. Internet Journal of Advanced Nursing 10, 7. Available: http://ispub.com/IJANP/10/1/7218 (Accessed 12 November 2015).

Elisei S, Verdolini N \& Anastasi S (2012) Suicidal attempts among emergency department patients: One-year of clinical experience. Psychiatria Danubina 24, 140-142.

Evans SC, Roberts MC, Keeley JW, Blossom JB, Amaro CM, Garcia AM, Stough CO, Canter KS, Robles R \& Reed GM (2015) Vignette methodologies for studying clinicians' decision-making: Validity, utility, and application in ICD-11 field studies. International Journal of Clinical and Health Psychology 15, 160-170. DOI: 10.1016/j.ijchp.2014.12.001

Finfgeld DL (2003) Metasynthesis: the state of the art - so far. Qualitative Health Research 13, 893-904. DOI: $10.1177 / 1049732303253462$ 
*Forsyth A (2007) The effects of diagnosis and non-compliance attributions on therapeutic alliance processes in adult acute psychiatric settings. Journal of Psychiatric and Mental Health Nursing 14, 33-40. DOI: 10.1111/j.1365-2850.2007.01036.x.

*Forsyth A (2010) Community Mental Health Team's Constructions of Service Users with a Diagnosis of Borderline Personality Disorder: An Ethnographic Study. Northumbria Research Link. Available: http://nrl.northumbria.ac.uk/1623/1/forsyth.angus_prof.doc.pdf. (Accessed 25 September 2015)

*Fraser K \& Gallop R (1993) Nurses' confirming/disconfirming responses to patients diagnosed with borderline personality disorder. Archives of Psychiatric Nursing 7, 336-341.

*Gallop R, Lancee WJ \& Garfinkel P (1989) How nursing staff respond to the label Borderline Personality-Disorder. Hospital and Community Psychiatry 40, 815-819.

*Giannouli H, Perogamvros L, Berk A, Svigos A \& Vaslamatzis G (2009) Attitudes, knowledge and experience of nurses working in psychiatric hospitals in Greece, regarding borderline personality disorder: a comparative study. Journal of Psychiatric and Mental Health Nursing 16, 481-487. DOI: 10.1111/j.1365-2850.2009.01406.x

Gilburt H, Rose D \& Slade M (2008) The importance of relationships in mental health care: A qualitative study of service users' experiences of psychiatric hospital admission in the UK. BMC Health Services Research 8:92. DOI 10.1186/1472-6963-8-92

Godin G, Bélanger-Gravel A, Eccles M \& Grimshaw J (2008) Healthcare professionals' intentions and behaviours: A systematic review of studies based on social cognitive theories. BMC: Implementation Science 3: 36. DOI :10.1186/1748-5908-3-36

Grant BF, Chou SP, Goldstein RB, Huang B, Stinson FS, Saha TD, Smith SM, Dawson DA, Pulay AJ, Pickering RP \& Ruan WJ (2008) Prevalence, correlates, disability, and comorbidity of DSM-IV borderline personality disorder: Results from the Wave 2 National Epidemiologic Survey on Alcohol and Related Conditions. Journal of Clinical Psychiatry 69, 533-545.

Greenhalgh T (2006) How to Read a Paper: The Basics of Evidence Based Medicine. Blackwell: Malden, MA.

*Hauck J (2013) Psychiatric nurses' attitudes and persons with borderline personality disorder: focus on clinical practice, education, and best practices - a follow-up. Journal of the American Psychiatric Nurses Association 19, 33.

Hayashi N, Igarashi M, Imai A, Osawa Y, Utsumi K, Ishikawa Y, Tokunaga T, Ishimoto K, Harima H, Tatebayashi Y, Kumagai N, Nozu M, Ishii H \& Okazaki Y (2010) Psychiatric disorders and clinical correlates of suicidal patients admitted to a psychiatric hospital in Tokyo. BMC Psychiatry 10: 109. DOI:10.1186/1471-244X-10-109

*Hazelton M, Rossiter R \& Milner J (2006) Managing the 'unmanageable': training staff in the use of dialectical behaviour therapy for borderline personality disorder. Contemporary Nurse 21, 120-130. 
*Herschell AD, Lindhiem OJ, Kogan JN, Celedonia KL \& Stein BD (2014) Evaluation of an implementation initiative for embedding Dialectical Behavior Therapy in community settings. Evaluation and Program Planning 43, 55-63. DOI: 10.1016/j.evalprogplan.2013.10.007

Hughes R \& Huby M (2002) The application of vignettes in social and nursing research. Journal of Advanced Nursing 37, 382-386. DOI: 10.1046/j.1365-2648.2002.02100.x

*James PD \& Cowman S (2007) Psychiatric nurses' knowledge, experience and attitudes towards clients with borderline personality disorder. Journal of Psychiatric and Mental Health Nursing 14, 670-678. DOI: 10.1111/j.1365-2850.2007.01157.x

*Kale K \& Dantu K (2015) Clinicians attitude towards patients with Borderline Personality. A Survey Summary. RCPsych in Wales ENewsletter - Winter/Spring. Available: http://www.rcpsych.ac.uk/workinpsychiatry/divisions/rcpsychinwales/news/enewsletterwinte r-spring2015.aspx (Accessed 25th September 2015)

*Knaak S, Szeto ACH, Fitch K, Modgill G \& Patten S (2015) Stigma towards borderline personality disorder: effectiveness and generalizability of an anti-stigma program for healthcare providers using a pre-post randomized design. Borderline Personality Disorder and Emotion Dysregulation 2:9. DOI: 10.1186/s40479-015-0030-0

*Krawitz R (2004) Borderline personality disorder: attitudinal change following training. Australian New Zealand Journal of Psychiatry 38, 554-559. DOI: 10.1111/j.14401614.2004.01409.x

*Krawitz R \& Batcheler M (2006) Borderline personality disorder: a pilot survey about clinician views on defensive practice. Australasian Psychiatry 14, 320-322.

DOI: $10.1111 /$ j.1440-1665.2006.02297.x

Látalová K \& Praško J (2010) Aggression in Borderline Personality Disorder. Psychiatric Quarterly 81, 239-251. DOI 10.1007/s11126-010-9133-3

Lieb K, Zanarini MC, Schmahl C, Linehan PMM \& Bohus PM (2004) Borderline personality disorder. Lancet 364, 453-461. DOI: 10.1155/2012/601918

*Ma W, Shih F, Hsiao S, Shih S \& Hayter M (2009) 'Caring Across Thorns' - Different care outcomes for borderline personality disorder patients in Taiwan. Journal of Clinical Nursing 18, 440-450. DOI: 10.1016/j.evalprogplan.2013.10.007

*Markham D (2003) Attitudes towards patients with a diagnosis of 'borderline personality disorder': Social rejection and dangerousness. Journal of Mental Health 12, 595-612.

DOI:10.1186/s12888-014-0380-yI

*Markham D \& Trower P (2003) The effects of the psychiatric label 'borderline personality disorder' on nursing staffs perceptions and causal attributions for challenging behaviours. British Journal of Clinical Psychology 42, 243-256. DOI: 10.1348/01446650360703366 
*McGrath B \& Dowling M (2012) Exploring registered psychiatric nurses' responses towards service users with a diagnosis of borderline personality disorder. Nursing Research and Practice. DOI: 10.1155/2012/601918. (Accessed 25 September)

*Miller SA \& Davenport NC (1996) Increasing staff knowledge of and improving attitudes toward patients with borderline personality disorder. Psychiatric Services 47, 533-535.

Moher D, Liberati A, Tetzlaff J \& Altman DG (2009) Preferred reporting items for systematic reviews and meta-analyses: the PRISMA statement. BMJ 339, .b2535. Available: http://www.bmj.com/content/339/bmj.b2535. (Accessed 25 September 2015)

*Nehls N (2000) Being a case manager for persons with borderline personality disorder: Perspectives of community mental health center clinicians. Archives of Psychiatric Nursing 14, 12-18. DOI: http://dx.doi.org/10.1016/S0883-9417(00)80004-7

Newton-Howes G, Weaver T \& Tyrer P (2008) Attitudes of staff towards patients with personality disorder in community mental health teams. Australian and New Zealand Journal of Psychiatry 42, 572-577. DOI: 10.1080/00048670802119739

Nursing and Midwifery Council. (2015) The Code: Professional standards of practice and behaviour for nurses and midwives. London: Author.

http://www.nmc.org.uk/globalassets/sitedocuments/nmc-publications/revised-new-nmccode.pdf (Accessed 18 ${ }^{\text {th }}$ November 2015)

*O’Brien L \& Flöte J (1997) Providing nursing care for a patient with borderline personality disorder on an acute inpatient unit: a phenomenological study. Australian and New Zealand Journal of Mental Health Nursing, 6, 137-147.

*O'Connell B \& Dowling M (2013) Community psychiatric nurses' experiences of caring for clients with borderline personality disorder. Mental Health Practice 17, 27-33. DOI:

10.7748/mhp2013.12.17.4.27.e845

Ryan CJ \& Bowers L (2005) Coercive manoeuvres in a psychiatric intensive care unit. Journal of Psychiatric and Mental Health Nursing 12, 695-702. DOI: 10.1111/j.13652850.2005.00899.x

Saunders KEA, Hawton K, Fortune S \& Farrell S (2012) Attitudes and knowledge of clinical staff regarding people who self-harm: A systematic review. Journal of Affective Disorders 139, 205-216. DOI:10.1016/j.jad.2011.08.024

Schreiber, R., Crooks, D., \& Stern, P.N. (1997) Qualitative meta-analysis. In: Completing a qualitative project: Details and dialogue. J.M. Morse [Ed]. Sage: Thousand Oaks, CA, 311326.

*Shanks C, Pfohl B, Blum N \& Black DW (2011) Can negative attitudes toward patients with borderline personality disorder be changed? The effect of attending a STEPPS workshop.

Journal of Personality Disorders 25, 806-812. DOI:10.1521/pedi.2011.25.6.806 
Sniehotta FF, Presseau J \& Araujo-Soares V (2014) Time to retire the theory of planned behaviour. Health Psychology Review 8, 1-7. DOI: 10.1080/17437199.2013.869710

*Stringer B, van Meijel B, Karman P, Koekkoek B, Hoogendorn AW, Kerkhof AJFM \& Beekman ATF (2014a) Collaborative care for patients with severe personality disorders: preliminary results and active ingredients from a pilot study (Part I). Perspectives in Psychiatric Care 51, 180-189. DOI: 10.1111/ppc.12079

Stringer B, van Meijel B, Karman P, Koekkoek B, Kerkhof AJFM \& Beekman ATF (2014b) Collaborative care for patients with severe personality disorders: analyzing the execution process in a pilot study (Part II). Perspectives in Psychiatric Care 51, 220-227. DOI: $10.1111 /$ ppc. 12087

*Strong S (2010) The Effects of the Label Borderline Personality Disorder on Staff Attributions and Intended Behaviour. Doctoral thesis. Available at: https://ueaeprints.uea.ac.uk/20501/1/2010STRONGSCCLINPSYD.pdf (Accessed 25 September 2015)

* Stroud J \& Parsons R (2013) Working with borderline personality disorder: A small-scale qualitative investigation into community psychiatric nurses' constructs of borderline personality disorder. Personality and Mental Health 7, 242-253. DOI: 10.1002/pmh.1214

Tong A, Sainsbury P \& Craig J (2007) Consolidated criteria for reporting qualitative research (COREQ): a 32-item checklist for interviews and focus groups. International Journal for Quality in Health Care 19, 349-357. DOI: http://dx.doi.org/10.1093/intqhc/mzm042

*Treloar AJC \& Lewis AJ (2008) Professional attitudes towards deliberate self-harm in patients with borderline personality disorder. Australian and New Zealand Journal of Psychiatry 42, 578-584.

University of York Centre for Reviews and Dissemination (2008) Systematic reviews: CRD's guidance for undertaking reviews in health care. Available: https://www.york.ac.uk/media/crd/Systematic_Reviews.pdf (Accessed 25 September 2015)

*Walthall M (2013) Clinicians' Attitudes Towards Borderline Personality Disorder and Posttraumatic Stress Disorder: Implications of Gender and a Diagnostic Label. Available: https://dspace.smith.edu/bitstream/handle/11020/24255/MarjaWalthallThesisfinal\%281\%29. pdf? sequence $=1 \&$ isAllowed $=y($ Accessed 9 October 2015)

*Warrender D (2015) Staff nurse perceptions of the impact of mentalization-based therapy skills training when working with borderline personality disorder in acute mental health: a qualitative study. Journal of Psychiatric and Mental Health Nursing 22,8, 559-652. DOI: $10.1111 / j p m .12248$

Westwood L \& Baker J (2010) Attitudes and perceptions of mental health nurses towards borderline personality disorder clients in acute mental health settings: a review of the literature. Journal of Psychiatric and Mental Health Nursing 17, 657-662. DOI: 10.1111/j.1365-2850.2010.01579.x 
*Woollaston K \& Hixenbaugh P (2008) 'Destructive whirlwind': Nurses' perceptions of patients diagnosed with borderline personality disorder. Journal of Psychiatric and Mental Health Nursing 15, 703-709. DOI: 10.1111/j.1365-2850.2008.01275.x 
Table 1: Inclusion and exclusion criteria

\begin{tabular}{lll}
\hline Parameter & Inclusion criteria & Exclusion criteria \\
\hline Population & $\begin{array}{l}\text { Sample includes mental health } \\
\text { nurses }\end{array}$ & Does not include mental health nurses \\
Intervention/Focus & $\begin{array}{l}\text { Responses (behavioural or } \\
\text { attitudinal responses to, experience } \\
\text { of, and knowledge about) about } \\
\text { borderline personality disorder or } \\
\text { people with this diagnosis } \\
\text { Responses to other diagnostic } \\
\text { groups, responses of other } \\
\text { professional groups. No }\end{array}$ & $\begin{array}{l}\text { Responses related to personality } \\
\text { disorder in general with no separate } \\
\text { data for borderline personality disorder }\end{array}$ \\
comparator. & None \\
Qualitative or quantitative accounts, & Opinion \\
Time period & $\begin{array}{l}\text { descriptions,comparisons. } \\
\text { Any }\end{array}$ & None \\
\hline
\end{tabular}

Table 2: Example search

\begin{tabular}{lll}
\hline Search term & Results \\
\hline 1$)$ & Borderline personality disorder & 1,532 \\
$2)$ & Emotionally unstable personality disorder & 9 \\
$3)$ & 1 OR 2 & 1,539 \\
$4)$ & Nurs* & 687,188 \\
$5)$ & Mental & 134,375 \\
$6)$ & Psychiatr* & 71,497 \\
$7)$ & 5 OR 6 & 173,877 \\
$8)$ & 4 AND 7 & 33,804 \\
$9)$ & Attitud* & 202,493 \\
$10)$ & Perce* & 188,454 \\
$11)$ & Belie* & 49,040 \\
$12)$ & Knowledg* & 116,229 \\
$13)$ & Stereotyp* & 6,625 \\
$14)$ & Stigma* & 11,814 \\
$15)$ & Opinion* & 22,035 \\
$16)$ & View* & 63,090 \\
$17)$ & Disposition* & 3,464 \\
$18)$ & Reaction & 51,803 \\
$19)$ & Stand* & 250,853 \\
$20)$ & Feel* & 27,950 \\
$21)$ & Impression* & 5,144 \\
$22)$ & Judg* & 18,128 \\
$23)$ & Characteri* & 151,731 \\
$24)$ & Experien* & 213,903 \\
$25)$ & $9,10,11,12,13,14,15,16,17,18,19,20,21,22$, OR 23 & 994,800 \\
$26)$ & 3 AND 8 AND 24 & 82 \\
\hline Emits: & \\
\hline
\end{tabular}

Limits: English language only 
Table 3: Quantitative studies quality assessment

\begin{tabular}{|c|c|c|c|c|c|c|c|c|c|c|c|c|c|}
\hline Study & $\begin{array}{l}\text { Explicit } \\
\text { aims }\end{array}$ & $\begin{array}{l}\text { Sample size } \\
\text { justification }\end{array}$ & $\begin{array}{c}\text { Research } \\
\text { independent of } \\
\text { routine practise }\end{array}$ & $\begin{array}{c}\text { Well } \\
\text { described } \\
\text { sample }\end{array}$ & $\begin{array}{l}\text { Representative } \\
\text { sample }\end{array}$ & $\begin{array}{l}\text { Explicit inclusion/ } \\
\text { exclusion criteria }\end{array}$ & $\begin{array}{c}\text { High } \\
\text { response rate } \\
(50 \%+) \\
\end{array}$ & $\begin{array}{c}\text { Questionnaire } \\
\text { development } \\
\text { described }\end{array}$ & $\begin{array}{l}\text { Validity and } \\
\text { reliability } \\
\text { justified }\end{array}$ & $\begin{array}{l}\text { Question } \\
\text { wording } \\
\text { available }\end{array}$ & $\begin{array}{c}\text { Discussion of } \\
\text { generalisability }\end{array}$ & $\begin{array}{c}\text { Statement } \\
\text { of funding } \\
\text { source }\end{array}$ & $\begin{array}{c}\text { Total } \\
\text { Score } \\
\text { (max. 12) }\end{array}$ \\
\hline Amey (1993) & + & - & - & + & + & + & + & + & - & + & + & - & 8 \\
\hline Black et al. (2011) & + & - & - & + & - & - & - & - & - & + & + & + & 5 \\
\hline Bodner et al. (2015) & + & - & - & + & + & + & - & + & - & + & + & - & 7 \\
\hline Bodner et al. (2011) & + & - & - & + & + & + & - & + & & + & + & - & 7 \\
\hline Clark et al. (2015) & + & - & - & + & + & - & + & + & 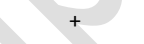 & + & + & + & 9 \\
\hline Cleary et al. (2002) & + & - & - & + & + & + & - & + & 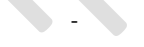 & + & + & - & 7 \\
\hline Commons Treloar \& Lewis (2008) & + & - & - & + & + & - & - & + & + & + & + & + & 8 \\
\hline Deans \& Meocevic (2006) & + & - & - & + & + & + & + & + & - & + & + & - & 8 \\
\hline Forsyth (2007) & + & - & + & + & + & + & - & + & - & + & + & - & 8 \\
\hline Fraser \& Gallop (1993) & + & - & - & - & - & - & - & + & - & - & - & - & 2 \\
\hline Gallop et al. (1989) & + & - & - & + & - & - & + & + & + & + & + & - & 7 \\
\hline Giannouli et al. (2009) & + & - & - & + & + & + & + & + & - & + & - & - & 7 \\
\hline Hauck et al. (2013) & + & - & - & + & + & + & + & + & + & + & + & + & 10 \\
\hline Herschell et al. (2014) & + & - & + & + & + & + & + & + & - & + & + & + & 10 \\
\hline James \& Cowman (2007) & - & - & - & + & - & + & - & + & - & - & + & - & 4 \\
\hline Knaak et al. (2015) & + & - & + & + & & + & + & + & - & + & + & + & 9 \\
\hline Krawitz (2004) & + & - & - & + & - & + & + & + & - & + & + & - & 7 \\
\hline Krawitz \& Batcheler (2006) & + & - & - & - & - & - & - & - & - & + & + & - & 3 \\
\hline Markham \& Trower (2003) & + & - & + & - & - & - & + & + & - & - & - & - & 4 \\
\hline Markham (2003) & + & - & - & + & + & + & + & + & + & + & - & - & 8 \\
\hline Miller \& Davenport (1996) & + & - & - & & - & + & - & + & + & - & + & - & 5 \\
\hline Shanks et al. (2011) & + & - & + & & - & + & + & + & - & + & - & + & 7 \\
\hline Stringer et al. (2015) & + & - & + & + & - & + & - & - & - & - & + & + & 5 \\
\hline Strong (2010) & + & + & + & + & + & + & - & + & + & + & + & + & 11 \\
\hline Treloar \& Lewis (2008) & + & - & - & + & - & + & - & + & + & - & - & - & 5 \\
\hline Walthall (2013) & + & - & - & - & - & + & - & - & + & + & - & - & 4 \\
\hline
\end{tabular}




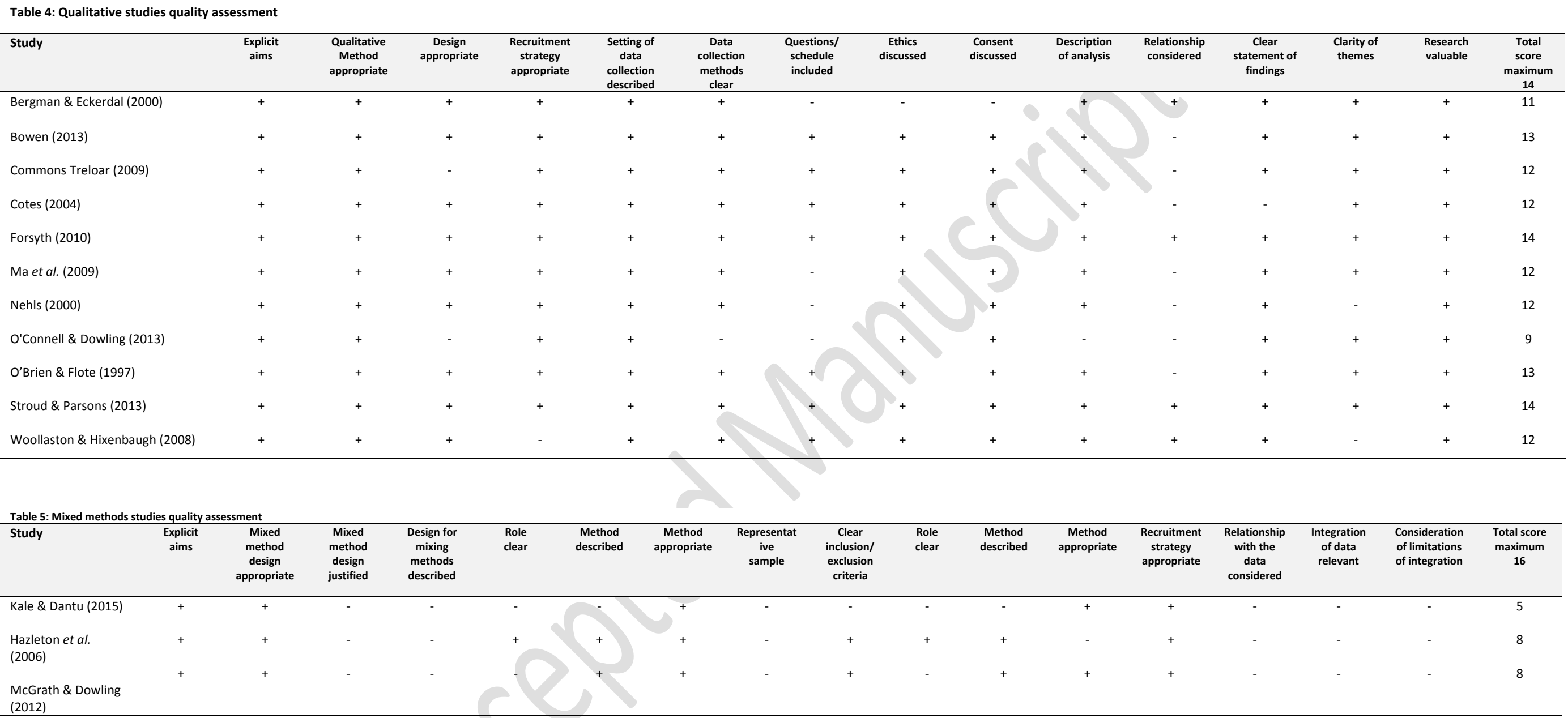




\section{Table 6: Included study details}

\begin{tabular}{|c|c|}
\hline Study & Purpose/research question \\
\hline Amey (1993) & $\begin{array}{l}\text { Do nurses stereotype BPD patients compared with those with schizophrenia or } \\
\text { affective disorder? }\end{array}$ \\
\hline $\begin{array}{l}\text { Bergman \& } \\
\text { Eckerdal (2000) }\end{array}$ & What does it mean for caregivers to manage BPD patients? \\
\hline $\begin{array}{l}\text { Black et al. } \\
\text { (2011) }\end{array}$ & $\begin{array}{l}\text { Explore attitudes to people with a BPD diagnosis among mental health clinicians } \\
\text { and compare among occupational subgroups. }\end{array}$ \\
\hline $\begin{array}{l}\text { Bodner,et al. } \\
\text { (2011) }\end{array}$ & $\begin{array}{l}\text { i) Compare attitudes between occupational groups; ii) Explore the relationship } \\
\text { between BPD-related emotional and cognitive attitudes }\end{array}$ \\
\hline $\begin{array}{l}\text { Bodner et al. } \\
\text { (2015) }\end{array}$ & $\begin{array}{l}\text { To obtain further evidence about nurses' relatively negative attitudes toward } \\
\text { people diagnosed with BPD in a larger sample than in Bodner et al. (2011). }\end{array}$ \\
\hline Bowen (2013) & $\begin{array}{l}\text { To explore experiences of good practice among mental health professionals } \\
\text { working in a specialist BPD treatment service }\end{array}$ \\
\hline $\begin{array}{l}\text { Clark et al. } \\
\text { (2015) }\end{array}$ & $\begin{array}{l}\text { Does a brief training session improve staff knowledge and understanding of BPD, } \\
\text { and empathy towards patients diagnosed with BPD? }\end{array}$ \\
\hline $\begin{array}{l}\text { Cleary et al. } \\
\text { (2002) }\end{array}$ & $\begin{array}{l}\text { To provide baseline data about staffs' experience, knowledge and attitudes } \\
\text { regarding management of people with BPD. }\end{array}$ \\
\hline $\begin{array}{l}\text { Commons } \\
\text { Treloar (2009) }\end{array}$ & $\begin{array}{l}\text { Explore accounts of working with BPD patients, and the difficulties that have } \\
\text { contributed to reported negative attitudes in the literature }\end{array}$ \\
\hline $\begin{array}{l}\text { Commons } \\
\text { Treloar \& Lewis } \\
\text { (2008) }\end{array}$ & $\begin{array}{l}\text { To examine the effect of attending targeted clinical education on clinician } \\
\text { attitudes towards working with deliberate self harm behaviours in BPD. }\end{array}$ \\
\hline Cotes (2004) & $\begin{array}{l}\text { Examine the experiences of professionals working with people diagnosed with } \\
\text { BPD, explore the stressors, and the processes used to cope with them }\end{array}$ \\
\hline $\begin{array}{l}\text { Deans \& } \\
\text { Meocevic } \\
\text { (2006) }\end{array}$ & $\begin{array}{l}\text { To describe psychiatric nurses' attitudes towards individuals diagnosed with } \\
\text { BPD. }\end{array}$ \\
\hline Forsyth (2007) & $\begin{array}{l}\text { Do mental health workers' cognitive processes vary across diagnoses for clients } \\
\text { with BPD or major depressive disorder? Do differences impact on emotional } \\
\text { reactions and intended helping? }\end{array}$ \\
\hline Forsyth (2010) & Describe the beliefs of mental health nurses towards BPD service users \\
\hline $\begin{array}{l}\text { Fraser \& Gallop } \\
\text { (1993) }\end{array}$ & $\begin{array}{l}\text { Do BPD patients receive less empathic verbal responses from nurses than } \\
\text { patients diagnosed with schizophrenia or affective disorder }\end{array}$ \\
\hline $\begin{array}{l}\text { Gallop et al. } \\
\text { (1989) }\end{array}$ & $\begin{array}{l}\text { To assess nurses' expressed empathy to people labelled with BPD or } \\
\text { schizophrenia diagnoses. }\end{array}$ \\
\hline $\begin{array}{l}\text { Giannouli et al. } \\
\text { (2009) }\end{array}$ & $\begin{array}{l}\text { To determine the BPD-related knowledge and attitudes of nurses working in } \\
\text { psychiatric hospitals and in clinics in general hospitals }\end{array}$ \\
\hline $\begin{array}{l}\text { Hauck et al. } \\
\text { (2013) }\end{array}$ & $\begin{array}{l}\text { To explore attitudes of psychiatric nurses toward hospitalized BPD patients with } \\
\text { deliberate self-harm behaviours }\end{array}$ \\
\hline $\begin{array}{l}\text { Hazelton et al. } \\
\text { (2006) }\end{array}$ & $\begin{array}{l}\text { Evaluation of effect of staff training in the use of } \\
\text { Dialectical Behaviour Therapy (DBT) at baseline (T1), 1-month post-training (T2) } \\
\text { and 6-month follow-up (T3) }\end{array}$ \\
\hline
\end{tabular}

\begin{tabular}{|c|c|c|c|}
\hline Sample & Country & Setting & Design \\
\hline $\begin{array}{l}N=20 \text { registered nurses with }>6 \text { months } \\
\text { experience }\end{array}$ & Canada & $\begin{array}{l}\text { Inpatient acute mental } \\
\text { health unit }\end{array}$ & $\begin{array}{l}\text { Experimental, within-subjects design. Attitudes to diagnostic groups } \\
\text { compared with existing ratings of individual patients with BPD, affective } \\
\text { disorder or schizophrenia }\end{array}$ \\
\hline$N=29$ caregivers ( $n=18$ nurses) & Sweden & $\begin{array}{l}\text { Mental health } \\
\text { in/outpatient service }\end{array}$ & $\begin{array}{l}\text { Descriptive, qualitative. In-depth individual interviews. Grounded theory } \\
\text { approach. }\end{array}$ \\
\hline $\begin{array}{l}N=706 \text { mental health clinicians ( } n=97 \\
\text { nurses) }\end{array}$ & US & $\begin{array}{l}\text { Nine academic/ clinical } \\
\text { centres }\end{array}$ & Descriptive, cross-sectional survey study \\
\hline $\begin{array}{l}N=57 \text { mental health clinicians }(n=25 \\
\text { nurses) age }>25 \text { years, }>1 \text { year's } \\
\text { experience. }\end{array}$ & Israel & Psychiatric institutions & Descriptive, cross-sectional survey study \\
\hline $\begin{array}{l}N=710 \mathrm{MH} \text { clinicians ( } n=262 \text { nurses) age } \\
>25 \text { years, }>1 \text { year's experience }\end{array}$ & Israel & Four psychiatric hospitals & $\begin{array}{l}\text { Cross-sectional between-subjects and experimental, within-subjects survey } \\
\text { design elements to compare attitudes towards BPD and major depressive } \\
\text { disorder (MDD) or Generalised Anxiety Disorder (GAD) diagnoses. }\end{array}$ \\
\hline $\begin{array}{l}N=9 \text { clinicians including } 4 \text { nurses with at } \\
\text { least 1-year experience. }\end{array}$ & UK & $\begin{array}{l}\text { Specialist residential BPD } \\
\text { therapeutic community } \\
\text { unit. }\end{array}$ & $\begin{array}{l}\text { Descriptive, qualitative. Individual semi-structured 1-1.5 hour interviews. } \\
\text { Thematic analysis used. }\end{array}$ \\
\hline$N=34$ MDT staff ( $n=23$ nurses). & UK & $\begin{array}{l}\text { 23-bed low secure mental } \\
\text { health unit for women } \\
\text { with BPD. }\end{array}$ & $\begin{array}{l}\text { Experimental before- after study. Intervention: Psychologist-delivered } \\
\text { lecture based on neurobiological understanding of BPD. }\end{array}$ \\
\hline$N=229$ MDT staff ( $n=152$ nurses). & Australia & $\begin{array}{l}\text { Mental health inpatient } \\
\text { and community services }\end{array}$ & Descriptive, cross-sectional questionnaire survey. \\
\hline $\begin{array}{l}N=140 \text { health practitioners }(n=93[69 \%] \\
\text { nurses). }\end{array}$ & $\begin{array}{l}\text { Australia \& New } \\
\text { Zealand }\end{array}$ & $\begin{array}{l}\text { Emergency medicine and } \\
\text { mental health services in } \\
\text { three hospitals. }\end{array}$ & $\begin{array}{l}\text { Descriptive, qualitative. Free-written response to a 1-item questionnaire. } \\
\text { Thematic analysis. }\end{array}$ \\
\hline $\begin{array}{l}N=99 \text { registered practitioners }(n=75 \\
\text { nurses) who encounter patients with } \\
\text { BPD in their work. }\end{array}$ & $\begin{array}{l}\text { Australia \& New } \\
\text { Zealand }\end{array}$ & $\begin{array}{l}\text { Three emergency } \\
\text { medicine and mental } \\
\text { health services of three } \\
\text { hospitals. }\end{array}$ & $\begin{array}{l}\text { Experimental before-after study. Intervention: } 90 \text { minute evidence-based } \\
\text { lecture about attitudes to BPD, prevalence, DSM-IV diagnostic criteria, } \\
\text { aetiology, definitions and rates of self-harm and suicide, and therapeutic } \\
\text { responses, case studies and } 30 \text { minute seminar. }\end{array}$ \\
\hline$N=4$ professionals ( $n=1$ nurse) & UK & $\begin{array}{l}\text { Community mental } \\
\text { health team }\end{array}$ & $\begin{array}{l}\text { Descriptive, qualitative. Semi-structured interviews. Interview schedule } \\
\text { phenomenological analysis. }\end{array}$ \\
\hline $\begin{array}{l}N=47 \text { registered psychiatric nurses with } \\
1+\text { year experience }\end{array}$ & Australia & $\begin{array}{l}\text { Inpatient/ community } \\
\text { mental health services }\end{array}$ & Descriptive, non-comparative, cross-sectional questionnaire survey \\
\hline $\begin{array}{l}N=26 \text { registered nurses and support } \\
\text { workers }\end{array}$ & UK & $\begin{array}{l}\text { Four inpatient wards, one } \\
\text { psychiatric intensive care } \\
\text { unit in one NHS Trust }\end{array}$ & 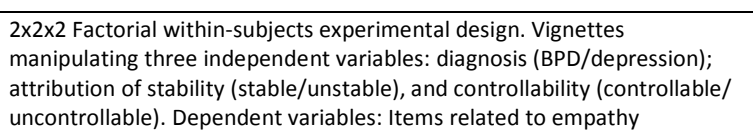 \\
\hline $\begin{array}{l}\text { Clinical team discussions and interviews } \\
\text { with } N=3 \text { nurses }\end{array}$ & UK & $\begin{array}{l}\text { Community mental } \\
\text { health team }\end{array}$ & $\begin{array}{l}\text { Descriptive, qualitative, ethnographic: observation at assessment and } \\
\text { referral meetings and interviews. Social constructionist perspective. }\end{array}$ \\
\hline$N=17$ nurse leaders. & Canada & Inpatient psychiatric units & $\begin{array}{l}\text { Observational study of nurses' behaviour in therapeutic groups. Within- } \\
\text { subjects design. }\end{array}$ \\
\hline$N=113$ registered nurses & Canada & Inpatient acute wards. & Within-subjects experimental survey design. \\
\hline$N=69$ nurses & Greece & $\begin{array}{l}15 \text { psychiatric wards in } \\
\text { psychiatric and general } \\
\text { medical hospitals }\end{array}$ & Descriptive, cross-sectional survey \\
\hline$N=83$ registered nurses & US & $\begin{array}{l}\text { Inpatient units in three } \\
\text { psychiatric hospitals. }\end{array}$ & Descriptive/ correlational cross-sectional questionnaire survey. \\
\hline $\begin{array}{l}\text { T1: } N=69 \text { staff }(67 \% \text { registered } \\
\text { psychiatric nurses), T2: } N=38 \text { ( } 72 \% \\
\text { nurses); } T 3: N=24 \text { ( } 42 \% \text { nurses) plus } \\
\text { focus groups with } N=24 \text { at } T 1 \text { and } N=18\end{array}$ & Australia & $\begin{array}{l}\text { Mental health service } \\
\text { comprising inpatient, } \\
\text { community, liaison and } \\
\text { rehabilitation teams }\end{array}$ & $\begin{array}{l}\text { Mixed-methods: i) Descriptive, longitudinal survey; ii) Descriptive, } \\
\text { qualitative. Pre- and post- training focus groups. } \\
\text { Intervention: 2-day basic (and for some 2-day advanced) training on } \\
\text { implementation of DBT. Discourse analysis }\end{array}$ \\
\hline
\end{tabular}




\begin{tabular}{|c|c|c|c|c|c|}
\hline & & at T2.. & & & \\
\hline Study & Purpose/research question & Sample & intry & Setting & Design \\
\hline $\begin{array}{l}\text { Herschell et al. } \\
\text { (2014) }\end{array}$ & $\begin{array}{l}\text { (1) Evaluate the effectiveness of the implementation of DBT model components } \\
\text { on therapist attitudes, confidence in DBT model effectiveness, and use of DBT } \\
\text { components. (2) understand what practitioner variables are important to } \\
\text { outcomes }\end{array}$ & $N=68(n=913 \%$ registered nurses $)$ & US & $\begin{array}{l}\text { Community mental } \\
\text { health centres }\end{array}$ & $\begin{array}{l}\text { Experimental before-after survey design. Questionnaires administered pre- } \\
\text { initial } 5 \text { day DBT training; baseline }+6 \text { months and immediately before } \\
\text { second 5-day DBT training; baseline }+14 \text { months and immediately before } \\
\text { final 2-day training; baseline }+22 \text { months Intervention: intensive DBT } \\
\text { training, and support phone consultation }\end{array}$ \\
\hline $\begin{array}{l}\text { James \& } \\
\text { Cowman (2007) }\end{array}$ & $\begin{array}{l}\text { To contribute to understanding of nurses' knowledge, experiences and attitudes } \\
\text { towards the care of clients with BPD. }\end{array}$ & $N=65$ qualified nurses & Ireland & $\begin{array}{l}\text { Adult inpatient, } \\
\text { community, day } \\
\text { hospitals, rehabilitation } \\
\text { units/hostels }\end{array}$ & Descriptive, cross-sectional survey design \\
\hline $\begin{array}{l}\text { Kale \& Dantu } \\
\text { (2015) }\end{array}$ & $\begin{array}{l}\text { To gather opinions from clinicians including mental health and A\&E staff } \\
\text { about interactions with patients with BPD. }\end{array}$ & $N=91$ staff ( $n=29$ nurses; $32 \%)$ & UK & $\begin{array}{l}\text { Professional working in } \\
\text { one University Health } \\
\text { Board }\end{array}$ & $\begin{array}{l}\text { Mixed-methods: } 10 \text { questions including two open questions about reason } \\
\text { for discomfort and what they would do differently next time. }\end{array}$ \\
\hline $\begin{array}{l}\text { Knaak et al. } \\
\text { (2015) }\end{array}$ & $\begin{array}{l}\text { To measure the impact of an educational intervention on attitudes and } \\
\text { behavioural intentions of healthcare providers towards persons with BPD. }\end{array}$ & $N=191$ clinicians ( $n=27$ nurses) & Canada & $\begin{array}{l}\text { Inpatient, community and } \\
\text { outreach service } \\
\text { providers attending a } \\
\text { training event }\end{array}$ & $\begin{array}{l}\text { Experimental, before-after survey study. Random allocation to responding } \\
\text { about attitudes to BPD or mental illness in general. Intervention: Three } \\
\text { hour educational/social-contact workshop on BPD and DBT }\end{array}$ \\
\hline Krawitz (2004) & $\begin{array}{l}\text { To assess the effect of training workshop on clinician attitudes to working with } \\
\text { people with a diagnosis of BPD. }\end{array}$ & $\begin{array}{l}N=418 \text { ( } 46 \% \text { nurses) mental health } \\
\text { clinicians }\end{array}$ & Australia & $\begin{array}{l}\text { Public mental health and } \\
\text { substance abuse services } \\
\text { at a training workshop. }\end{array}$ & $\begin{array}{l}\text { Experimental before-after survey study. Intervention: 2-day workshop on } \\
\text { BPD diagnosis, aetiology, prognosis, and treatment; detailed discussion of } \\
\text { treatment principles }\end{array}$ \\
\hline $\begin{array}{l}\text { Krawitz \& } \\
\text { Batcheler(2006) }\end{array}$ & $\begin{array}{l}\text { To assess the frequency of defensive practice in treating adults with a BPD } \\
\text { diagnosis }\end{array}$ & $N=29$ clinicians ( $n=14$ nurses; $48 \%$ ) & New Zealand & $\begin{array}{l}\text { Adult community, } \\
\text { inpatient and crisis } \\
\text { mental health services. }\end{array}$ & Descriptive. Cross-sectional survey. \\
\hline $\begin{array}{l}\text { 26. Ma et al. } \\
\text { (2009) }\end{array}$ & $\begin{array}{l}\text { To explore the contributing factors and effects of Taiwanese nurses' decision- } \\
\text { making patterns on care outcomes for patients with BPD. }\end{array}$ & $\begin{array}{l}N=15 \text { experienced ( } 3+\text { years) nurses with } \\
\text { recent BPD experience }\end{array}$ & China & $\begin{array}{l}\text { Acute or rehabilitation } \\
\text { unit of a psychiatric } \\
\text { centre in northern } \\
\text { Taiwan }\end{array}$ & $\begin{array}{l}\text { Descriptive, qualitative. In-depth interviews. Analysis guided by Guba and } \\
\text { Lincoln's (1994) naturalistic inquiry method. }\end{array}$ \\
\hline $\begin{array}{l}\text { Markham \& } \\
\text { Trower (2003) }\end{array}$ & $\begin{array}{l}\text { How does the BPD label influence staff's causal attributions relative to those } \\
\text { with schizophrenia or affective disorder? How do these relate to staff sympathy, } \\
\text { optimism, and evaluation of personal experience? }\end{array}$ & $N=48$ Registered mental health nurses & UK & $\begin{array}{l}\text { Adult or older adult } \\
\text { inpatient facilities. }\end{array}$ & $\begin{array}{l}\text { Experimental/correlational within-subjects, survey design. Independent } \\
\text { variable: diagnosis. Dependent variables: stability and control attributions, } \\
\text { sympathy, optimism, experience }\end{array}$ \\
\hline $\begin{array}{l}\text { Markham } \\
\text { (2003) }\end{array}$ & $\begin{array}{l}\text { To assess the association of staff ratings of their personal experience of working } \\
\text { with BPD, schizophrenia and affective disorder groups on ratings of social } \\
\text { rejection and dangerousness. }\end{array}$ & $\begin{array}{l}N=71 \text { (mental health nurses } n=50 ; n=21 \\
\text { health care assistants) }\end{array}$ & UK & $\begin{array}{l}\text { Mental health inpatient } \\
\text { wards }\end{array}$ & $\begin{array}{l}\text { Experimental factorial between (nurses vs. care assistants) and within } \\
\text { groups survey design. Dependent variables: responses to vignettes with } \\
\text { BPD, schizophrenia and depression scenarios }\end{array}$ \\
\hline $\begin{array}{l}\text { McGrath \& } \\
\text { Dowling (2012) }\end{array}$ & $\begin{array}{l}\text { (1) identify common themes about nurses' reported interactions with BPD } \\
\text { patients; (ii) describe nurses BPD-related empathy }\end{array}$ & $\begin{array}{l}N=17 \text { experienced nurses with BPD } \\
\text { experience }\end{array}$ & Ireland & $\begin{array}{l}\text { Community mental } \\
\text { health service }\end{array}$ & $\begin{array}{l}\text { Mixed-methods: Qualitative semi-structured interviews. Thematic analysis. } \\
\text { Descriptive, cross-sectional survey using quantitative attitudinal scale to } \\
\text { measure response to vignettes involving first time vs. multiple admission } \\
\text { scenarios. }\end{array}$ \\
\hline $\begin{array}{l}\text { Miller \& } \\
\text { Davenport } \\
\text { (1996) }\end{array}$ & $\begin{array}{l}\text { Evaluate an educational intervention on nursing staffs' knowledge of, attitudes } \\
\text { to and behavioural intention towards BPD patients }\end{array}$ & $N=32$ registered nurses & US & $\begin{array}{l}\text { Four acute psychiatric } \\
\text { units in general hospitals }\end{array}$ & $\begin{array}{l}\text { Experimental between subjects (intervention vs. no intervention) non- } \\
\text { randomised controlled trial. Intervention: Self-paced programmed } \\
\text { instruction using a } 31 \text { page booklet about the aetiology, dynamics and } \\
\text { treatment of BPD }\end{array}$ \\
\hline Nehls (2000) & $\begin{array}{l}\text { To better understand the views of case managers about case management of } \\
\text { BPD patients with as it is practiced and experienced }\end{array}$ & $\begin{array}{l}N=17 \text { case managers (profession unclear } \\
\text { but nursing implied) }\end{array}$ & US & $\begin{array}{l}\text { Community mental } \\
\text { health centre }\end{array}$ & $\begin{array}{l}\text { Descriptive, qualitative. Semi structured interviews. } \\
\text { Interpretative phenomenology used to analyse }\end{array}$ \\
\hline $\begin{array}{l}\text { O'Brien \& Flöte } \\
\text { (1997 }\end{array}$ & $\begin{array}{l}\text { To explore the experiences of nurses who had cared for 'Mary-Ann', a patient } \\
\text { with BPD, multiple admissions, and self-harming behaviour }\end{array}$ & $\begin{array}{l}N=6 \text { nurses with 1+ year experience with } \\
\text { experience of caring for 'Mary Ann' }\end{array}$ & Australia & $\begin{array}{l}\text { Inpatient acute } \\
\text { psychiatric unit }\end{array}$ & $\begin{array}{l}\text { Qualitative. Semi-structured interviews. } \\
\text { Hermeneutic phenomenology used to analyse responses. }\end{array}$ \\
\hline
\end{tabular}




\begin{tabular}{|c|c|c|c|c|c|}
\hline $\begin{array}{l}\text { O'Connell \& } \\
\text { Dowling (2013) }\end{array}$ & $\begin{array}{l}\text { To explore the experience of community-based psychiatric nurses who work } \\
\text { with BPD patients }\end{array}$ & $N=10$ registered psychiatric nurses & Ireland & $\begin{array}{l}\text { Community mental } \\
\text { health team }\end{array}$ & Descriptive, qualitative. Semi-structured interview. Thematic analysis. \\
\hline $\begin{array}{l}\text { Shanks et al. } \\
\text { (2011) }\end{array}$ & Evaluation of impact of an educational 1-day workshop on on attitudes & $\begin{array}{l}N=271 \text { clinicians (<6\% nurses) } \\
\text { experienced in diagnosing/treating BPD. }\end{array}$ & US & Workshop for clinicians & $\begin{array}{l}\text { Experimental within subjects before-after study. Intervention: Systems } \\
\text { Training for Emotional Predictability and Problem Solving (STEPPS) group } \\
\text { treatment program for BPD }\end{array}$ \\
\hline Study & Purpose/research question & Sample & \multirow{2}{*}{$\begin{array}{l}\text { Country } \\
\text { Netherlands }\end{array}$} & Setting & Design \\
\hline $\begin{array}{l}\text { Stringer et al. } \\
\text { (2015) }\end{array}$ & $\begin{array}{l}\text { To describe the preliminary outcomes of a collaborative care programme (CCP) } \\
\text { for patients with a severe borderline or NOS personality disorder in comparison } \\
\text { with care as usual (CAU). Study examined attitudes of nurses pre- and post- } \\
\text { implementation }\end{array}$ & $\begin{array}{l}N=14 \text { nurses ( } 9 \text { trained in CCP, } 5 \\
\text { offering CAU) }\end{array}$ & & $\begin{array}{l}\text { Two community mental } \\
\text { health teams }\end{array}$ & $\begin{array}{l}\text { Comparative multiple case study design. For investigation of attitudes of } \\
\text { nurses measures taken before and after implementation of programme } \\
\text { implementation. }\end{array}$ \\
\hline Strong (2010) & $\begin{array}{l}\text { (1)Do staffs' attributions and intended behaviour differ towards clients labelled } \\
\text { with BPD and depression?. (2) Explore the association between staffs' BPD- } \\
\text { knowledge and their attributions of controllability, dangerousness; and intended } \\
\text { behaviours. }\end{array}$ & $\begin{array}{l}N=83(n=35 \text { nurses and } 4 \text { student } \\
\text { nurses) mental health practitioners }\end{array}$ & UK & $\begin{array}{l}\text { Community }(90 \%+) \text { and } \\
\text { inpatient mental health } \\
\text { settings }\end{array}$ & $\begin{array}{l}\text { i) Experimental, between- groups (respond to vignettes about BPD vs. } \\
\text { BPD/Depressed patient). Dependent variable: dangerousness and } \\
\text { controllability and coercion and social distance. ii) Correlational design to } \\
\text { examine relationships between emotional reactions and intended } \\
\text { behaviour, knowledge and dangerousness; and controllability and coercion } \\
\text { and social distance }\end{array}$ \\
\hline $\begin{array}{l}\text { Stroud \& } \\
\text { Parsons (2013) }\end{array}$ & $\begin{array}{l}\text { To explore community psychiatric nurses' knowledge, attitudes and approach to } \\
\text { clients diagnosed with BPD. }\end{array}$ & $\begin{array}{l}N=4 \text { CPNs directly working with } \\
\text { people with BPD diagnosis }\end{array}$ & UK & $\begin{array}{l}\text { Community mental } \\
\text { health team }\end{array}$ & $\begin{array}{l}\text { Descriptive, qualitative. Semi-structured interview. Interpretative } \\
\text { Phenomenological Analysis. }\end{array}$ \\
\hline $\begin{array}{l}\text { Treloar \& Lewis } \\
\text { (2008) }\end{array}$ & $\begin{array}{l}\text { To assess the BPD-related attitudes of mental health and emergency medicine } \\
\text { clinicians }\end{array}$ & $\begin{array}{l}N=140 \text { ( } n=90 \text { nurses) registered } \\
\text { practitioners }\end{array}$ & $\begin{array}{l}\text { Australia \& New } \\
\text { Zealand }\end{array}$ & $\begin{array}{l}\text { Two Australian and one } \\
\text { New Zealand health } \\
\text { service }\end{array}$ & Descriptive, cross-sectional survey. \\
\hline Walthall, 2013 & $\begin{array}{l}\text { To investigate clinicians' diagnostic assessments of individuals who have } \\
\text { features present of both BPD and Post Traumatic Stress Disorder and the effect } \\
\text { of gender on that assessment. }\end{array}$ & $\begin{array}{l}N=45 \text { mental health clinicians } \\
\text { (including } n=1 \text { with a Masters } \\
\text { degree in nursing) }\end{array}$ & US & $\begin{array}{l}\text { Range of community and } \\
\text { inpatient settings. }\end{array}$ & $\begin{array}{l}\text { Experimental, between groups (vignette using no gendered } \\
\text { pronouns/female pronouns/male pronouns) survey design }\end{array}$ \\
\hline $\begin{array}{l}\text { Woollaston \& } \\
\text { Hixenbaugh } \\
\text { (2008) }\end{array}$ & $\begin{array}{l}\text { To give nurses a voice and evaluate the validity of current theories about nurses' } \\
\text { perceptions of patients who are diagnosed with BPD. }\end{array}$ & $\begin{array}{l}N=6 \text { members of psychiatric nursing } \\
\text { teams (including nursing assistants) }\end{array}$ & UK & $\begin{array}{l}\text { Inpatient/ community } \\
\text { mental health settings. }\end{array}$ & Descriptive, qualitative. Semi-structured interviews. Thematic analysis. \\
\hline
\end{tabular}


Figure 1: Flow diagram of literature search modified from the PRISMA flow diagram (Moher et al. 2009)

Number of records identified through database searching: 596
Number of records identified through other sources: 38

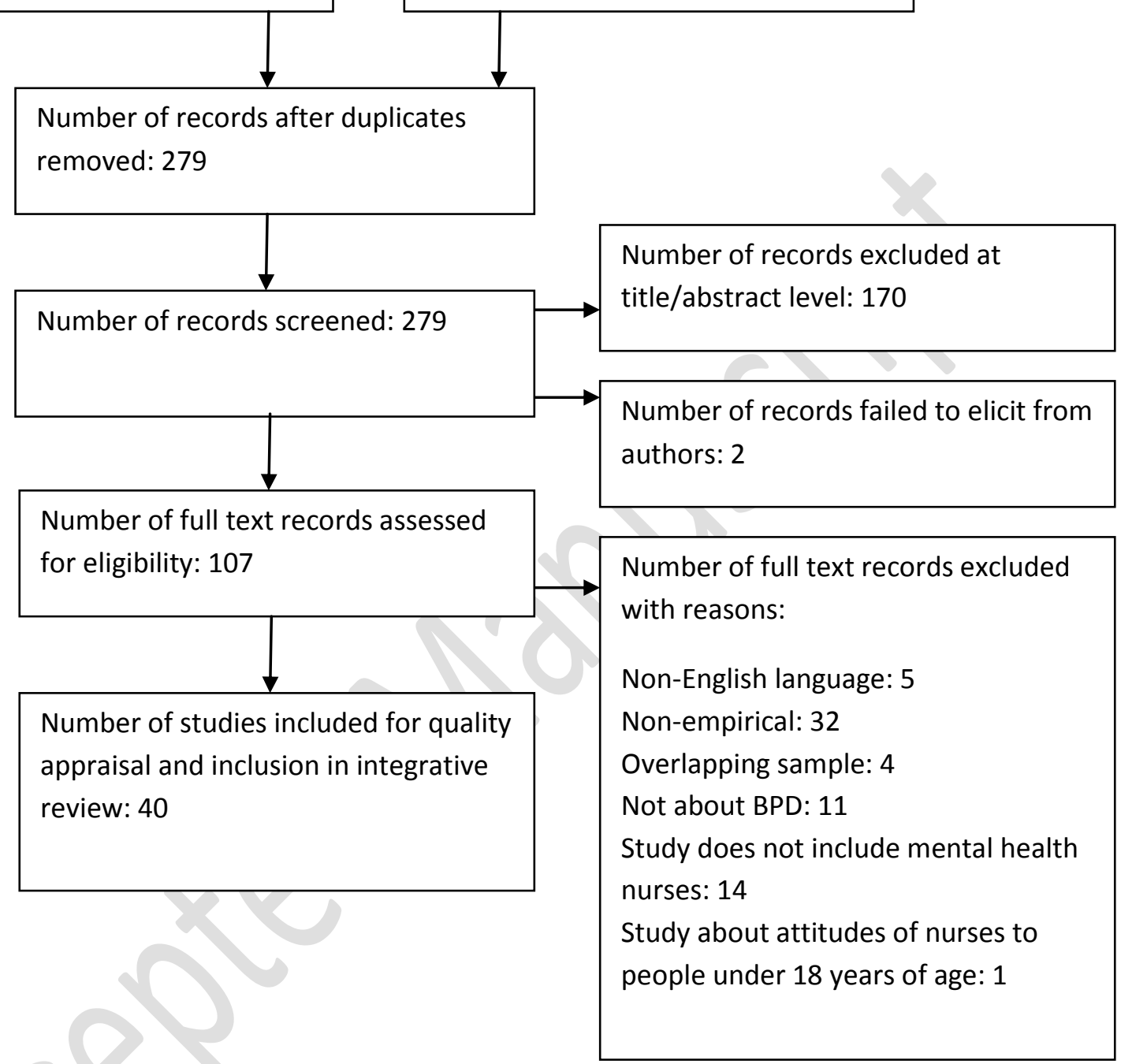

